\title{
The effect of soil fertility on antioxidant enzymes activity in a subarctic woody species
}

\author{
Kseniya Mihajlovna Nikerova*, Nataliya Alekseevna Galibina, Yuliya \\ Leonidovna Moshchenskaya, Irina Nikolaevna Sofronova, Marina \\ Nikolaevna Borodina, Elena Viktorovna Moshkina, Ludmila Ludvigovna \\ Novitskaya
}

Forest Research Institute of the Karelian Research Centre of the Russian Academy of Sciences, Pushkinskaya St. 11, Petrozavodsk 185910, Russia

\begin{abstract}
The influence of major nutrients' reserves (available to plants) - nitrogen $(\mathrm{N})$, phosphorus $(\mathrm{P})$, potassium $(\mathrm{K})$ - in the top $25-\mathrm{cm}$ layer of soil on the Karelian birch (Betula pendula Roth var. carelica (Mercl.) Hämet-Ahti) with non-figured and figured wood via the antioxidant enzymes' activity was investigated. The analysis of sites in area where Karelian birch trees with varying degree of figured wood intensity were growing was carried out. The cambial zone of the sample trees during active cambial growth period was studied for the activity of AOS enzyme complex (superoxide dismutase (SOD); catalase (CAT); peroxidase (POD); polyphenol oxidase (PPO)). Cellulose content and lignin content were studied. It was noticed that the availability of major nutrients in the investigated sites had influence on the degree of figured wood intensity in Karelian birch plants. Thus, non-figured and figured Karelian birch plants that grew on sites with various levels of major nutrients' reserves differed in the AOS enzymes' activity, which was a consequence of different xylogenesis scenarios in the studied birch forms. It was supposed, that the certain site conditions (N, P, K levels) formation could affect the degree of figured wood intensity, cellulose and lignin content. The $\mathrm{N}$ level and $\mathrm{P} / \mathrm{N}$ ratio had the most effects under the adequate K level. So AOS enzymes' complex activity could indicate differences in Karelian birch wood quality in sites that differ in soil fertility (N, P, K levels).
\end{abstract}

Key words: AOS enzymes' activity, xylogenesis, Betula pendula var. carelica, figured wood, soil fertility

DOI: $10.5817 / C P R 2021-1-5$

Received October 12, 2020, accepted June 3, 2021.

*Corresponding author: K. Nikerova $<$ knikerova@yandex.ru $>$

Acknowledgements: The study was carried out under state order to the Karelian Research Centre of the Russian Academy of Sciences (Forest Research Institute of KarRC RAS) and supported by the

Russian Foundation for Basic Research, grant № 19-04-00622 A. 


\section{Introduction}

Some tree species have a unique phenomenon - the ability to form different wood types, sometimes within the one trunk. Silver birch (Betula pendula Roth var. pendula) is one of the most wellknown objects for such investigations. It can form normal non-figured wood, and its form - Karelian birch (B. pendula Roth var. carelica (Mercl.) Hämet-Ahti) - has figured wood (Novitskaya and Kushnir 2006). The ornamental properties are associated with the features of its macro- and microstructure: pearly luster is due to the swirl of wood structural elements, and figured pattern is generated by large inclusions of parenchyma cells (Novitskaya et al. 2020). Different xylogenesis scenarios can be observed externally. Our previous studies demonstrated that there were differences in the anatomical and morphological, physiological and biochemical, and molecular genetic levels (Galibina et al. 2015a,b, 2016a,b, 2019a,b,c; Novitskaya et al. 2016, 2018, 2020; Nikerova et al. 2018, 2019a,b; Nikerova and Galibina 2017; Moshchenskaya et al. 2017,2019). At the same time, different metabolic schemes were noticed in the carbohydrate and antioxidant (AOS) metabolism enzymes under various xylogenesis scenarios (Kubler 1991, Robertson et al. 1995, Sudachkova et al. 2004, Foucart et al. 2006, Nomura et al. 2013, Galibina et al. 2015a,b, 2016a,b, 2019a,b,c; Novitskaya et al. 2016, 2020; Nikerova et al. 2018, 2019a,b; Nikerova and Galibina 2017, Moshchenskaya et al. 2017,2019; Iakimova and Woltering 2017).

Karelian birch trees with non-figured wood have following metabolic scheme like: sucrose is cleaved mainly by sucrose synthase (SS) under the control of the SUS1 gene and this process is accompanied by active structural cell wall components synthesis, exactly cellulose (Galibina et al. 2015a, 2016a; Moshchenskaya et al. 2017). An increase in the apoplast invertase (ApInv) activity is observed while fig- ured wood is formed (Galibina et al. 2015b). UDP-glucose is the main product of sucrose cleavage by SS. In particular, the SUS form associated with plasmalemma is a component of the cellulose synthase complex and supplies UDP-glucose for cellulose synthesis (Amor et al. 1992, Ruan et al. 2003, Fujii et al. 2010, Song et al. 2010). A variation in the SUS/ApInv activities ratio underlies the great variation in the degree of figured wood intensity observed in Karelian birch trees. As a result of increased ApInv activity in the cell, free hexoses' content increases instead of UDPglucose concentration. Hexoses, through inclusion in the pentose-phosphate pathway and the Krebs cycle, participate in the synthesis of reactive oxygen species (ROS) and phenolic compounds (Savidge 1996, Couee et al. 2006, Wellen and Thompson 2010, Borges et al. 2017), leading to AOS enzymes' activity increase (Galibina et al. 2015a, Nikerova and Galibina 2017, Nikerova et al. 2018, 2019a,b). Glucose, as a signaling molecule, can initiate the AOS enzymes activity ( $\mathrm{Hu}$ et al. 2012). The glucose can interact with ROS directly and form peroxidase oxidation substrates (Sin'kevich et al. 2009). As a result, the pathways of sucrose utilization are switched from cellulose synthesis (as in the formation of normal non-figured wood) to secondary metabolism reactions, which are accompanied by an increase in the AOS enzymes' activity. Moreover, their activity correlates with an increase in the degree of figured wood intensity, so activity can be used as diagnostic marker (Galibina et al. 2016b, Nikerova and Galibina 2017, Nikerova et al. 2021).

Xylogenesis is influenced by environmental conditions, especially soil conditions, mainly characterized by the content of basic nutrients such as nitrogen $(\mathrm{N})$, phosphorus $(\mathrm{P})$, and potassium $(\mathrm{K})$ (Dünisch and Bauch 1994, Beets et al. 2001, Rikala 2003, Punches 2004, Nawrot et al. 
2008, Fernández et al. 2011). It is possible to change soil conditions by applying different doses of fertilizers containing elements in a labile form. It is assumed that the knowledge of various mechanisms of xylogenesis regulation, including ecological-physiological aspect, can give a fundamental scientific base in order to influence the xylogenesis process (Fernández et al. 2011).

It is known that the soil fertility affects wood quality characteristics (Paul 1959), including wood density (Beets et al. 2001). A negative correlation between soil fertility and the density of spruce and pine wood was described in many works of the $20^{\text {th }}$ century (Jalava 1933, Ericson 1966, Hakkila 1966, Hakkila and Uusvaara 1968, Uusvaara 1974, Velling 1976, Saranpää 1983, Kärkkäinen and Dumell 1983). In particular, P deficiency can lead to an increase in wood density (Cown 1974). It is also mentioned that the intensity of the sapwood formation can increase with increasing site fertility (Punches 2004). K in soils is involved in many xylogenesis aspects, especially, it has a significant role in the xylem cells formation during active cambial growth (Dünisch and Bauch 1994, Kuhn et al. 1997, Wind et al. 2004). There are studies that note the complexity in the interaction of soil conditions and wood quality in plants growing in these conditions (Moya and Pérez 2008, Pokharel et al. 2014). This often does not allow to clear relationships. The effects of soil nutrient status especially $\mathrm{N}$ and $\mathrm{P}$ deficiency and periodic moisture stress on wood properties of eight-year-old radiata pine were quite minor (Harris et al. 1978). There is some evidence that adding certain micronutrients can extend the period of latewood production, thereby increasing latewood proportion and wood density, but the specifics of this interaction remain unclear (Punches 2004). The effects described in some works argue with each other. Poorer sites were observed to produce wood of lower density in European spruce and
Scots pine (Lassila 1931), but later the opposite was reported for Douglas-fir (Paul 1950, Wellwood 1952), European spruce (Klem 1957) and red pine (Jayne 1958).

It is known about Karelian birch plants that the range of ecological conditions of its growth is narrow and is determined by good lighting, temperature conditions that contribute to the intensive sucrose outflow from the leaves, and normal moisture (Novitskaya 2008). As a result of studying the places of Karelian birch natural distribution and analyzing the soils characteristics within its range, it was suggested that the Karelian birch does not spread both in the areas of very poor (Leptosols) and relatively rich soils (Cambisols) (Novitskaya 2008). The ability to form patterned wood is inherited; it does not appear in all Karelian birch trees. Plants with abnormal wood structure commonly constitute 50$70 \%$ of the total progeny, and they vary widely in pattern intensity. Soil $\mathrm{N}$ is a well-known factor that affects the wood quality (Pokharel et al. 2014). Soil conditions can affect physiological processes in plants, which is reflected in the changes of enzymes activity, including the carbohydrate and AOS metabolism enzymes (Tombesi et al. 1969, Zbieć et al. 1986, 1989; Gurgul and Herman 1994, Gordon et al. 1999, 2002; Chikov et al. 2003, Chikov and Bakirova 2004, Dani et al. 2005, Batasheva 2006, Wilson et al. 2008, Bruskova et al. 2009, Nikitin et al. 2010, Bourioug et al. 2014, Galibina et al. 2016a, b, 2019c; Nikitin and Izmailov 2016, Nikerova and Galibina 2017).

Besides it should be noted that there is very important effect of enhanced UV-B in a high arctic site and a subarctic site (Solheim et al. 2002). Understanding UV -B mediated stress and stress-defence responses, including ROS formation, activation of molecular targets, and induced antioxidant defences, therefore, has a generic relevance (Jansen et al. 2012). Indeed, upregulation of antioxidant defences may result in a degree of crosstolerance to- 
wards other stressors. UV-B acclimation has been shown to increase tolerance to, for example, low temperatures (ChalkerScott and Scott 2004). The UV-B induced increase in antioxidative defenses is further demonstrated by increases in both the reduction state and pool-size for antioxidants (Jansen et al. 2008). Moreover, numerous studies have reported upregulation of enzymatic antioxidant activities, including SOD, POD and CAT (Hideg et al. 2006, Agrawal and Rathore 2007, $\mathrm{Xu}$ et al. 2008). The existence of a tradeoff between the capacity to achieve high productivity and stress tolerance is generally assumed for plant growing in unfavourable environmental conditions, such as extreme temperatures, drought, water availability or nutrient deficiency (Alpert 2006, Hoermiller et al. 2017). For example, in the harsh Arctic environment, ambient levels of UV-B decrease photosynthetic performance of Arctic willow (Salix arctica) (Albert et al. 2011) and increased levels of ROS may be formed as a result of disruption of metabolic activities or owing to increased activity of membrane-localized NADPH-oxidase (Hideg and Vass 1996, Kalbina and Strid 2006). Many studies demonstrated that UV-B together with some other factors, for example Cd-treatment, induced oxidative stress via indirect mechanisms such as inhibition of antioxidative defense systems, or via the activation of ROSproducing enzymes ( $\mathrm{Zu}$ et al. 2010). This can indicate superior cross-adaptation ( $\mathrm{Zu}$ et al. 2010, Li et al. 2012).

In previous studies we investigated the effect of exogenous nitrate on SS, ApInv, POD activities in the trunks of silver birch and Karelian birch during cambial growth (Galibina et al. 2016a; Nikerova and Galibina 2017). In silver birch, nitrate application increased sucrose utilization by SS, promoting wood growth, and it did not affect the POD activity. In Karelian birch xylem, nitrates lead to a decrease in SS, ApInv and POD activities. This resulted in a decrease in wood growth (caused by SS decline) and a decrease in the amount of parenchyma, i.e. normalization of the wood structure (caused by ApInv decline). Exogenous nitrate application led to a change in the donor-acceptor relationships, which also affected the activities of SS, ApInv and POD both in birch trees of different forms, and in seedlings (Galibina et al. 2016c, Moshchenskaya and Nikerova 2016, Nikerova and Galibina 2017). An increase in the acceptor role of the leaf apparatus was observed in the studied plants. Fertilization stimulates crown vigor, thereby increasing growth rate. It also encourages the production and retention of sapwood, resulting in greater sapwood depth. Its impact on wood quality is highly dependent on crown position (Punches 2004).

In natural stands $\mathrm{N}$ nutrition affected POD activity in non-figured and figured wood in different ways. POD activity increase in non-figured wood was observed with an increase in available $\mathrm{N}$ in the soil. POD activity had only a tendency to increase in figured wood. It was noted that interactions were not so clear (Galibina et al. 2016b).

However, past studies have generally focused on $\mathrm{N}$ because it generally is the most limiting nutrient element to plants in the field. As another key nutrient element for photosynthesis, $\mathrm{P}$ is often the most limiting or second most limiting element to the aboveground primary productivity. It is suggested that uptake of $\mathrm{N}$ and $\mathrm{P}$ from organic matter by plant roots is enhanced by ectomycorrhizal fungi that were present in the forest stands (Ritter 2007, Danyagri and Dang 2014). However, the availability of $\mathrm{N}$ and its ratio to $\mathrm{P}$ level in the soil influence the expression of figure in the wood in Karelian birch, as indicated by variations in the activity of enzymes - SS, ApInv and nitrate reductase (NR). An increased supply of nitrate $\mathrm{N}$ to a plant entails a rise in NR activity, which negatively affects the formation of patterned wood (Galibina et al. 2019c). 
The present study investigates nonfigured and figured Karelian birch plants in the middle taiga subzone of Karelia $\left(62^{\circ} 16^{\prime} \mathrm{N}\right.$ and $\left.33^{\circ} 59^{\prime} \mathrm{E}\right)$ where heterogeneity within a podzolic soil was found. Different sites within the studied plantation differed in nitrogen reserves $(\mathrm{N}$, $\mathrm{kg} / \mathrm{ha}$ ), phosphorus reserves $(\mathrm{P}, \mathrm{kg} / \mathrm{ha})$ and potassium reserves $(\mathrm{K}, \mathrm{kg} / \mathrm{ha})$. It was noted that non-figured and figured Karelian birch plants with different figure intensity point were not evenly distributed. Probably, different site conditions influenced.

Such studies are conducted for the first time and seem to be very interesting for subarctic and arctic woodies because of cross-adaptation of plants' AOS to several factors. For Karelian birch they are temperature conditions, moisture conditions and discussed with present study soil conditions (Novitskaya 2008). Thus, the aim of the work was to characterize the AOS

\section{Methods}

\section{Plant material}

The objects of research were 25-yearold plants of Karelian birch (B. pendula var. carelica). We studied high-stemmed Karelian birch plants with non-figured and figured wood. All the plants were raised from seeds obtained by controlled pollination of Karelian birch plus trees. 49 trees

\section{Plant sampling}

The cambium of silver birch in Karelia is active from the second decade of June to the first decade of August (Novitskaya et al. 2020). The samples were collected at the end of June when the cambium of silver birch in Karelia is active.

«Windows» of $10 \mathrm{~cm} \times 6 \mathrm{~cm}$ size were excised on birch trunks, and the bark was separated from wood to sample xylem and phloem tissues. The xylem tissues comprising xylem mother cells and outer layers enzymes' complex in Karelian birch plants that differ in the degree of figured wood intensity under sites with different reserves of major soil nutrients $(\mathrm{N}, \mathrm{P}, \mathrm{K})$. And to evaluate influence of site fertility on wood quality of Karelian birch plants via cellulose and lignin content and AOS enzymes' activity. It should be emphasized that no such studies have been previously conducted for naturally growing Karelian birch plants.

We hypothesized that AOS enzymes' complex activity could indicate differences in Karelian birch wood quality in sites that differ in soil fertility (N, P, K levels). In addition, we expected an enhancement in the plants' ability to quench ROS by antioxidative defences such as SODs, CATs, PODs, PPOs in changed soil conditions. Studies in this aspect are not found in the known literature and therefore they are relevant.

were sampled in total.

Trees with figured wood were arranged into 3 groups according to the figure intensity (1-3 points, where 1 corresponds for the least intensive pattern and 3 - for the highest figure intensity) (Galibina et al. 2019c, Novitskaya et al. 2020).

of the current-year xylem growth were scraped off the wood surface. From the inner surface of the bark we excised phloem tissues comprising the cambial zone, the conducting phloem, and the innermost layers of non-conducting phloem. The samples of trunk tissues were examined under a light microscope. Samples for biochemical analyses were collected from 19 nonfigured and 30 figured trees of 3 figure intensity groups (point from 1 to 3 ). 
All plant samples were frozen in liquid nitrogen immediately and kept it in a low

\section{Description of sites}

We studied plants growing in the middle taiga subzone of Karelia $\left(62^{\circ} 16^{\prime} \mathrm{N}\right.$ and $33^{\circ} 59^{\prime} \mathrm{E}$ ). The study region belongs to the Baltic physiographic domain, and is representative of the boreal zone of Northwestern Russia. The region is located at the southeastern edge of the Baltic (Fennoscandian) crystalline shield. The plants were sampled from artificial plantations placed on former clearcuts after planting

\section{Biochemical analysis}

Plant tissues were ground in liquid nitrogen to a uniform mass and homogenized at $4^{\circ} \mathrm{C}$ in the buffer containing $50 \mathrm{mM}$ HEPES ( $\mathrm{pH}$ 7.5), $1 \mathrm{mM}$ EDTA, $1 \mathrm{mM}$ EGTA, $3 \mathrm{mM}$ DTT, $5 \mathrm{mM} \mathrm{MgCl}_{2}$ and $0.5 \mathrm{mM}$ PMSF. After 20-min. extraction, the homogenate was centrifuged at $10000 \mathrm{~g}$ for $20 \mathrm{~min}$. (MPW-351R, Poland). The sediment was washed in the buffer thrice. The pooled supernatant and sediment were dialyzed at $4^{\circ} \mathrm{C}$ for $18-20 \mathrm{~h}$ against tenfold diluted homogenization buffer. Enzymes activity was determined spectrophotometrically (Spectrophotometer SF-2000, OKB Spectr, Russia) (Galibina et al. 2019c).

Proteins in the extracts were quantified by the method of Bradford.

The activity of superoxide dismutase (SOD, EC 1.15.1.1) is determined by photoreduction inhibition of nitro blue tetrazolium (NBT). The incubation medium for determining the activity of SOD contains

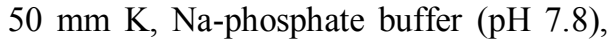
$172 \mu \mathrm{m}$ NBT, $210 \mu \mathrm{m}$ methionine, $24 \mu \mathrm{m}$ riboflavin, $0.1 \%$ Triton $\mathrm{X}-100$. In order to determine the activity of SOD, a decrease in the optical density at $560 \mathrm{~nm}$ after 30 minutes of incubation under the light of fluorescent lamps was measured. SOD activity is expressed in conventional units temperature freezer at $-80^{\circ} \mathrm{C}$ until the analysis was performed.

saplings grown from selected seeds. The plots differentiated by vegetative cover and soil properties. Soils of the study area were identified according to the International classification system of the World Reference Base ([1]-IUSS Working Group WRB 2015). The studied plot was established on a 2 ha. The soil is Gleyic Podzol. The plot is located in a low-lying part of the plantation with abundant moisture.

per $\mathrm{mg}$ of protein per 30 minutes $\left(\mathrm{U} \mathrm{mg}^{-1}\right.$ protein) (Nikerova et al. 2018, 2019b).

Catalase activity (CAT, EC 1.11.1.6) was determined by the enzymatic decomposition of hydrogen peroxide. The incubation medium contained $50 \mathrm{~mm} \mathrm{~K}$, Naphosphate buffer ( $\mathrm{pH} \mathrm{7.8)}$ and $14.7 \mathrm{~mm}$ hydrogen peroxide. Incubation time was 4 minutes. To determine the activity of CAT, a decrease in the optical density at $240 \mathrm{~nm}$ is measured, the $\mathrm{H}_{2} \mathrm{O}_{2}$ content was calculated according to a pre-constructed calibration. CAT activity was expressed in $\mu \mathrm{mol}$ of reduced hydrogen peroxide per mg of protein per 4 minutes $\left(\mu \mathrm{mol} \mathrm{H}_{2} \mathrm{O}_{2}\right.$ $\mathrm{mg}^{-1}$ of protein) (Nikerova et al. 2018, 2019a).

To determine the activity of peroxidase (POD, EC 1.11.1.7), guaiacol was used as a hydrogen donor, hydrogen peroxide was used as a substrate. The incubation medium for determining the activity of POD contained $50 \mathrm{~mm} \mathrm{~K}$, Na-phosphate buffer $(\mathrm{pH} 5), 2.6 \mathrm{~mm}$ hydrogen peroxide and $21.5 \mathrm{~mm}$ guaiacol. The incubation time was 30 minutes. POD activity was determined by the rate of formation of the reaction product of tetraguaiacol (TG). To determine the content of the formed TG, an increase in the optical density at $470 \mathrm{~nm}$ was measured, and the amount of TG was 
calculated taking into account the extinction coefficient $\left(\varepsilon 470 \mathrm{~nm}=0.0266 \mu \mathrm{m}^{-1}\right.$ $\left.\mathrm{cm}^{-1}\right)$. POD activity was expressed in $\mu \mathrm{mol}$ TG formed per $\mathrm{mg}$ of protein per $30 \mathrm{~min}-$

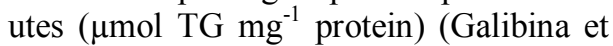
al. 2016b, Nikerova and Galibina 2017).

To determine the activity of polyphenoloxidase (PPO, 1.10.3.1) pyrocatechin was used as a substrate. The incubation medium for determining the activity of PPO contains $50 \mathrm{~mm} \mathrm{~K}$, Na-phosphate buffer ( $\mathrm{pH} 5$ ), $16.4 \mathrm{~mm}$ pyrocatechin. To determine the activity of the PPO, an increase in the optical density at a wavelength of $420 \mathrm{~nm}$ was measured, where pyrocatechin oxidation products were absorbed. Reaction monitoring time was 20 minutes. Activity of PPO was expressed

\section{Soil analyses}

Samples were collected from soil genetic horizons and analyzed following the techniques commonly used in soil science. The soil samples were sieved (with a mesh size of $2 \mathrm{~mm}$ ), and dried at room temperature and then in the oven at $105^{\circ} \mathrm{C}$ until constant weight. Total $\mathrm{N}$ was determined using ultimate CHNS analyzer (Perkin Elmer's 2400 Series II CHNS/O, USA). Labile $\mathrm{P}$ content was determined in the soil extracts $(0.2 \mathrm{~N} \mathrm{HCl})$ with ammonium molybdate (Tan 2005) spectrophotometrically (OKB Spektr SF-2000, Russia). The analysis of labile $\mathrm{K}$ content was performed by a flame atomic spectrophotometer (Shi-

\section{Statistical analyses}

Sample sizes are indicated as $\mathrm{n}$. The results were statistically processed with PAST (version 4.0). Pearson's correlation analysis between enzymes' activity, relations between enzymes activities, the cellulose and lignin content and reserves of major nutrients was performed. Enzyme activity data on each site in the diagrams appear as mean $\pm \mathrm{SD}$, where $\mathrm{SD}$ is the standard deviation*. Relations between en- in units per $\mathrm{mg}$ of protein per 1 minute ( $\mathrm{U} \mathrm{mg}^{-1}$ protein) (Nikerova et al. 2019b).

Cellulose was isolated by the Kürschner-Hoffer method (1929) using the mixture of concentrated nitric acid and ethanol in a proportion of 1:4 (v/v). Cellulose content was determined gravimetrically (Obolenskaya et al. 1991). The cellulose content was expressed as a percentage of DW.

To determine lignin, the plant material was previously extracted with ethyl alcohol to free it from resinous substances (Geles 2001). Lignin was then isolated by acid hydrolysis in $72 \%$ sulfuric acid. The lignin content was determined gravimetrically ([2]-TAPPI protocol, 2011) and expressed as a percentage of DW.

madzu AA 7000, Japan).

We calculated N, P and $\mathrm{K}$ reserves that were available to plants for all selected horizons of soil substrates. We took into account the litter for organic horizons and measured the thickness of mineral horizons. Reserves of N, P, K were calculated for the $0-25 \mathrm{~cm}$ layer, because it is there that the main forms of the nutrients available to plants are accumulated. Besides, this soil layer contained a large mass of plant roots. Nutrient reserves determined for individual soils were recalculated for the areas occupied by these soils in the landscape (Galibina et al. 2019c).

zymes activities in the diagrams appear as mean $\pm \mathrm{SE}$, where SE is the standard error. Before starting the statistical analysis, enzymes ratios data (CAT/SOD, POD/SOD, and CAT/POD) were initially tested for normality using the Shapiro-Wilk test. The significance of differences between variants were estimated by Mann-Whitney U-test. Spearman's rank test was performed to detect the dependence of enzyme ac- 
tivity on the figured wood formation intensity point. The significant difference was evaluated at the level of $p<0.05$.

*If one plant from the group of a certain degree of figured wood intensity was

\section{Results and Discussion}

\section{Soil condition variants}

The vegetation cover within the plantation was heterogeneous. The studied trees were located in small groups from 2 to 7 . In some sites only non-figured Karelian birch plants were observed. In others - Karelian birch plants with different degrees of figured wood intensity were found. Figured plants (with figured intensity point 3) were not found everywhere. Probably because of heterogeneous soil conditions. Therefore, in order to clarify the boundaries of soil differences and their possible sophisticated relationships with the location of plants with different degrees of figured wood intensity, individual soil analysis were performed for each group of studied plants at every site.

The demand for nutrients in birch depends on stand age and productivity, and is constrained by soil conditions. Birch trees consume nutrients most actively until the age of 30 years, after which the consumption declines sharply. Annual loss of essential nutrients from a circa 25 -year-old birch stand $12 \mathrm{~m}$ high is $74,8.3,25 \mathrm{~kg} / \mathrm{ha}$ (N, P, K, respectively) (Bazilevich and Titlyanova 2008).

Within the studied plot there were site variants different in the levels of natural fertility, as evidenced by the different reserves of major nutrients in the root layer found, then the standard deviation for triple analytical replication is indicated.

All assays were performed at the Core Facility of the Karelian Research Centre RAS.
(Table 1): $\mathrm{N}-60-166 \mathrm{~kg} / \mathrm{ha}, \mathrm{P}-28-127$ $\mathrm{kg} / \mathrm{ha}, \mathrm{K}-73-180 \mathrm{~kg} / \mathrm{ha}$.

Thus, Karelian birch non-figured plants were located at all the studied sites, except for the $8^{\text {th }}$ site. Figured plants (with figured intensity point 3) were not found everywhere. They were found on the site 2 , site 4 , site 6 , site 9 . Non-figured plants and figured plants (with figured intensity point 2 ) were on the site 1 , site 5 , site 7 . Nonfigured plants and figured plants (with figured intensity point from 1 to 3 ) were on the site 6 and on the site 8 . All groups of figured plants were found on the site 2 , except for the figured plants with figured intensity point 2 , and on the site 4 , except for figured plants with figured intensity point 1 (Table 1, Fig. 1).

\begin{tabular}{|c|c|c|c|}
\hline Site & $\mathbf{N , ~ k g / h a}$ & $\mathbf{P , ~ k g} / \mathbf{h a}$ & $\mathbf{K}, \mathbf{~ k g} / \mathbf{h a}$ \\
\hline $\mathbf{1}$ & 60 & 105 & 180 \\
\hline $\mathbf{2}$ & 69 & 102 & 100 \\
\hline $\mathbf{3}$ & 77 & 70 & 99 \\
\hline $\mathbf{4}$ & 78 & 122 & 180 \\
\hline $\mathbf{5}$ & 80 & 28 & 128 \\
\hline $\mathbf{6}$ & 85 & 127 & 167 \\
\hline $\mathbf{7}$ & 85 & 40 & 73 \\
\hline $\mathbf{8}$ & 108 & 124 & 138 \\
\hline $\mathbf{9}$ & 166 & 58 & 145 \\
\hline
\end{tabular}

Table 1. Reserves of major nutrients (available to plants) in the top $25-\mathrm{cm}$ layer of soil.

\section{The antioxidant enzymes activity in Karelian birch plants with different figured wood formation intensity point in xylem and in phloem in studied site variants}

Diagrams below demonstrate the activity of the studied enzymes in xylem and phloem tissues in trees with different degrees of figured wood intensity, taken within each individual site (Fig. 1). 
Site variant 1

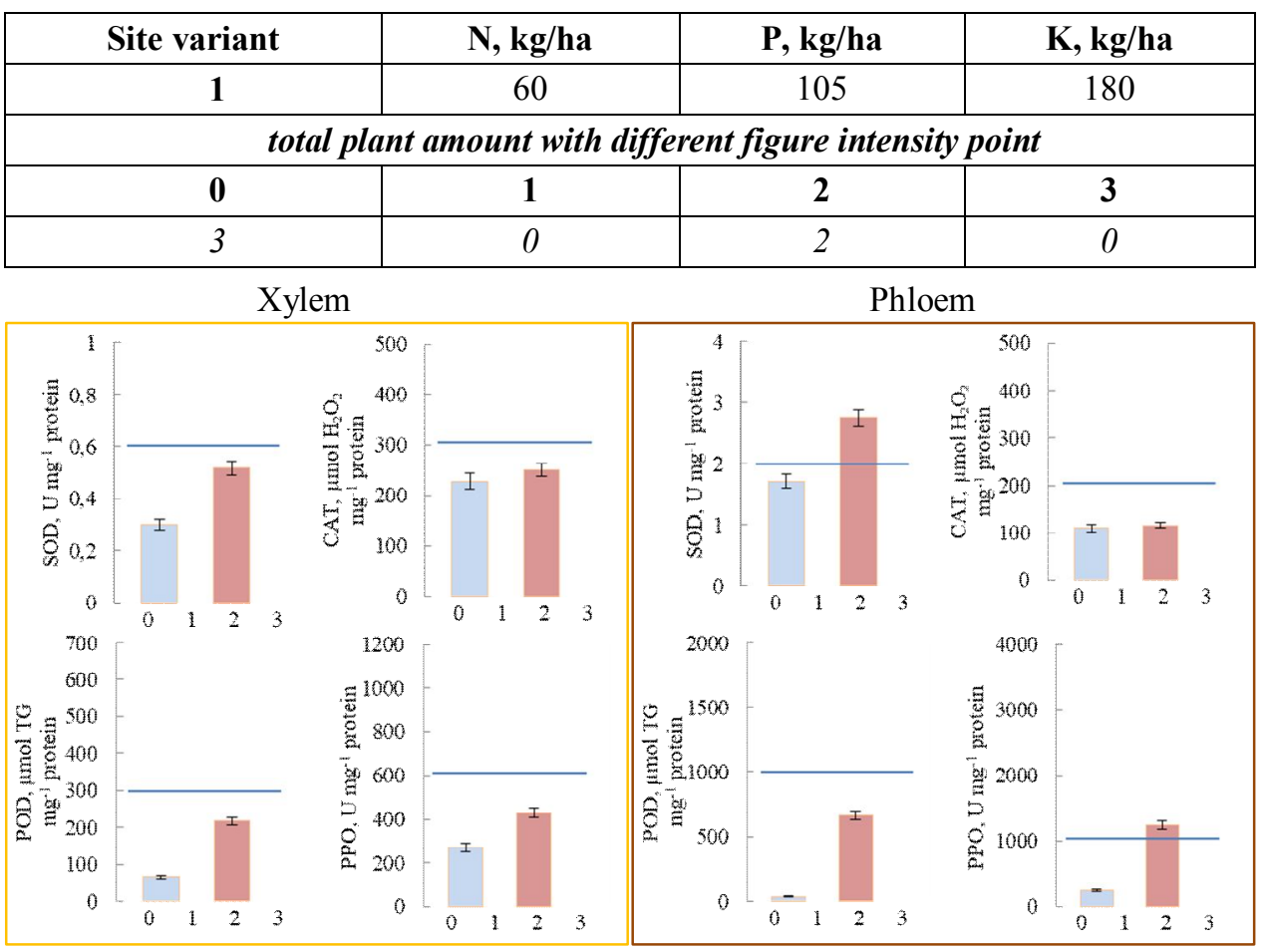

Site variant 2

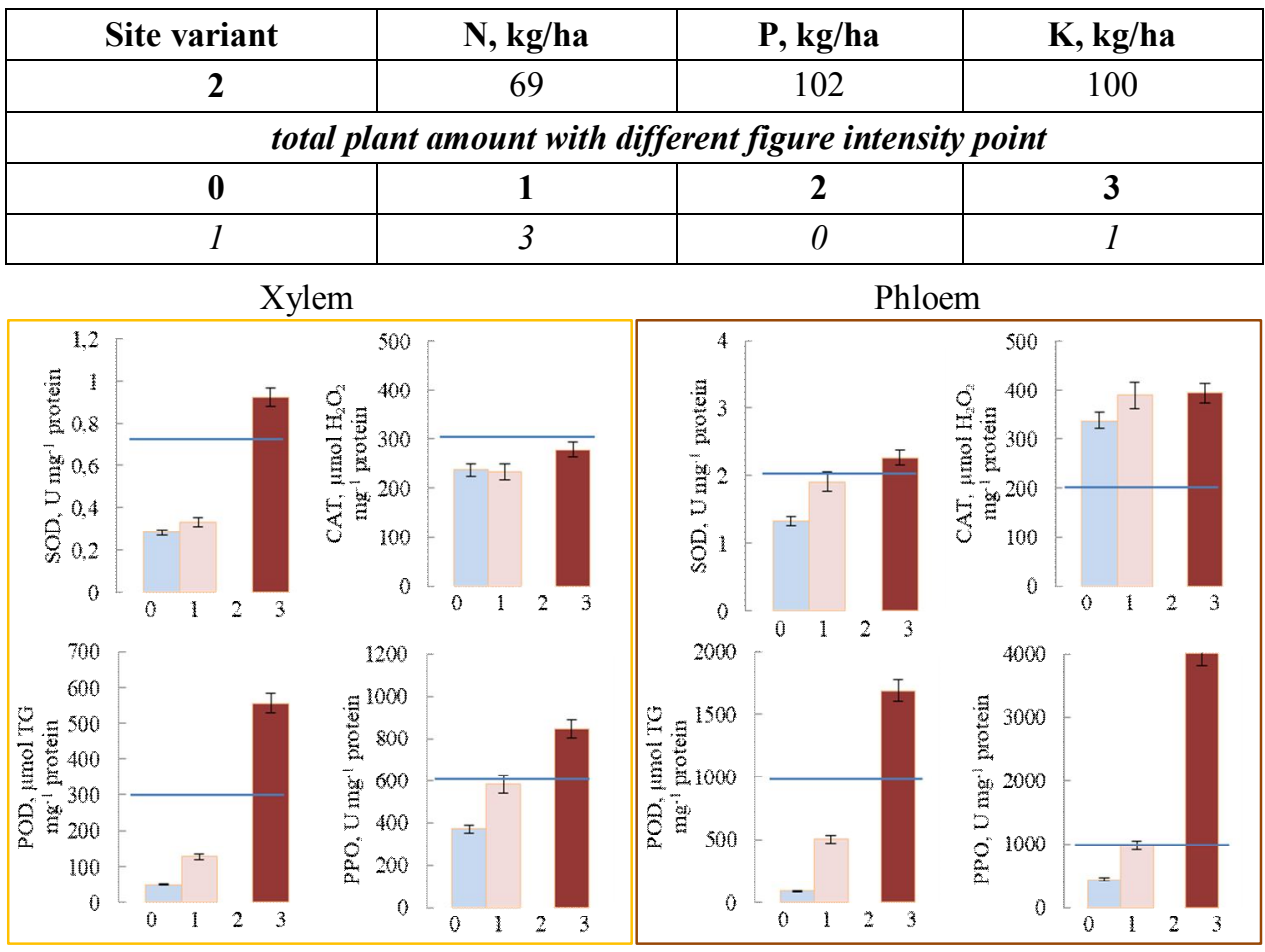


K. NIKEROVA et al.

Site variant 3

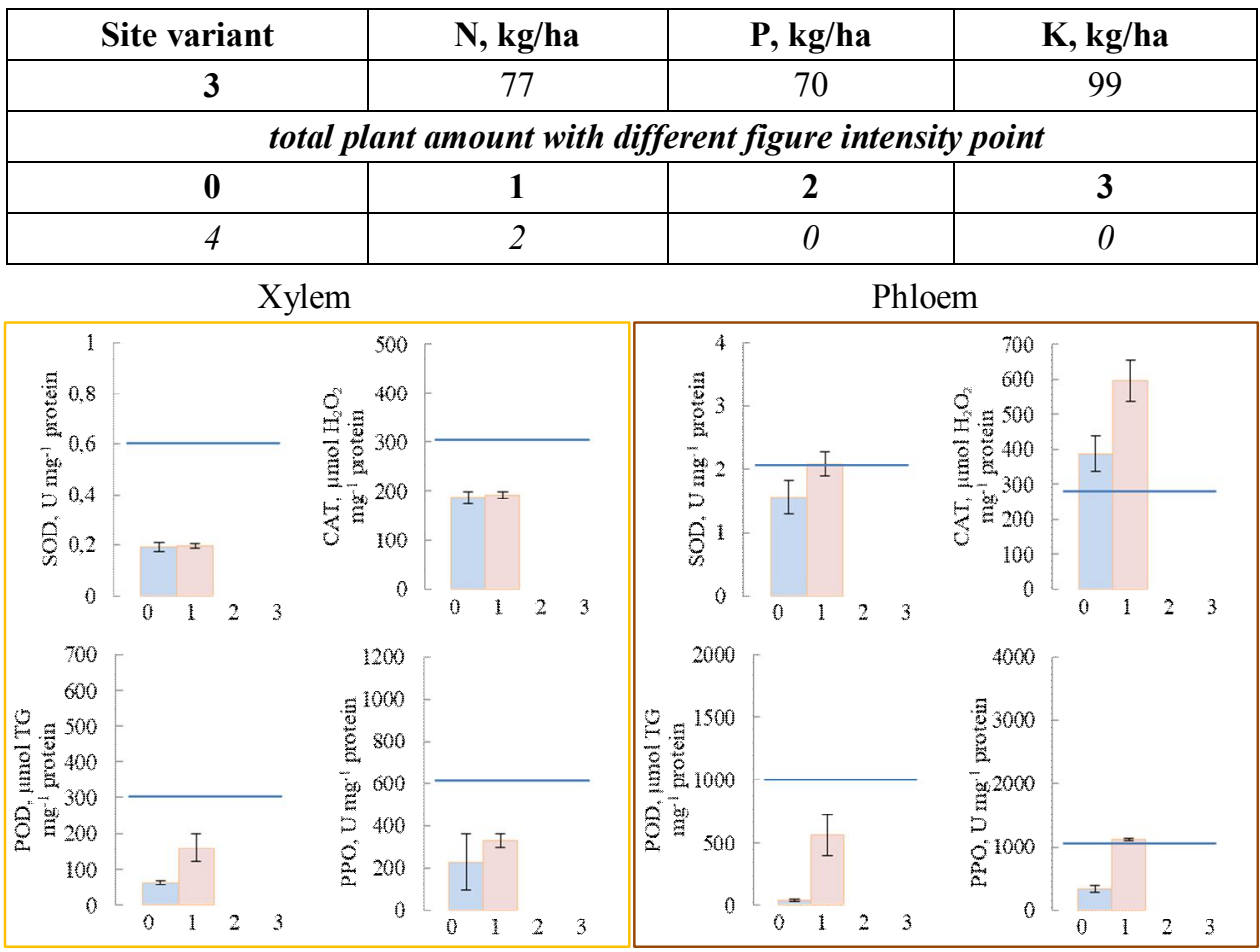

Site variant 4

\begin{tabular}{|c|c|c|c|}
\hline Site variant & $\mathbf{N}, \mathbf{~ k g} / \mathbf{h a}$ & $\mathbf{P}, \mathbf{~ k g} / \mathbf{h a}$ & $\mathbf{K}, \mathbf{~ k g} / \mathbf{h a}$ \\
\hline $\mathbf{4}$ & 78 & 122 & 180 \\
\hline \multicolumn{4}{|c|}{ total plant amount with different figure intensity point } \\
\hline $\mathbf{0}$ & $\mathbf{1}$ & $\mathbf{2}$ & $\mathbf{3}$ \\
\hline 2 & 0 & 2 & 1 \\
\hline
\end{tabular}

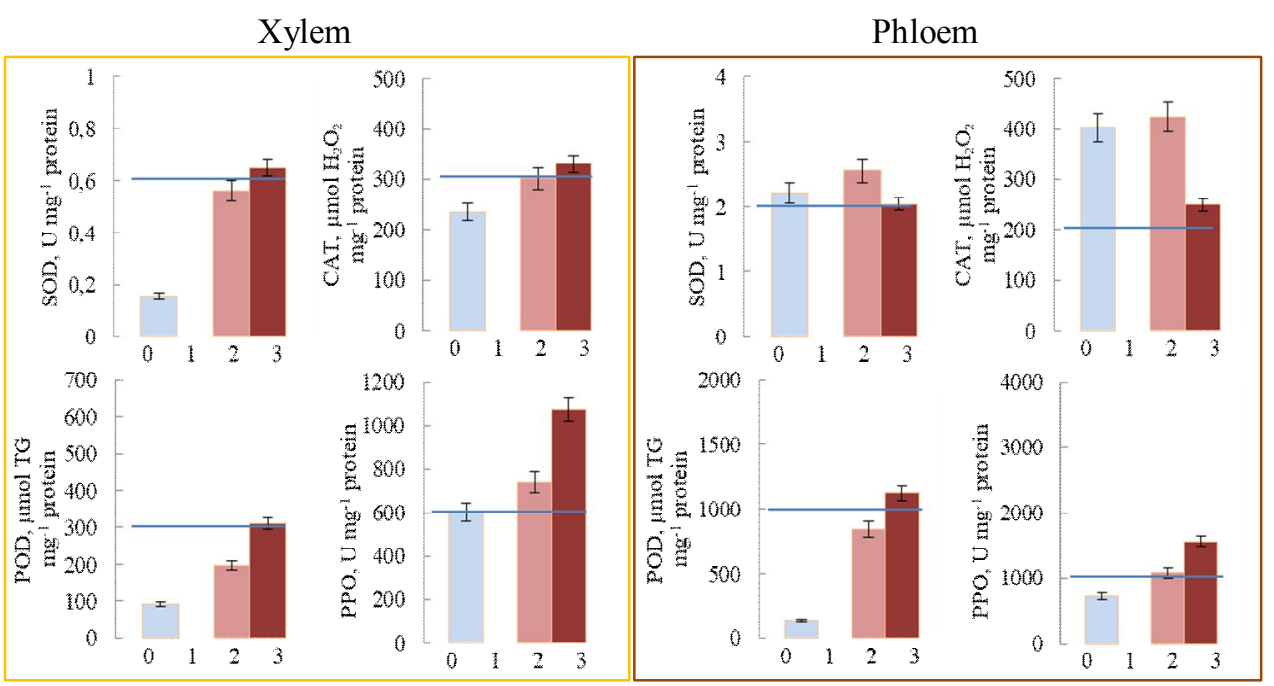


Site variant 5

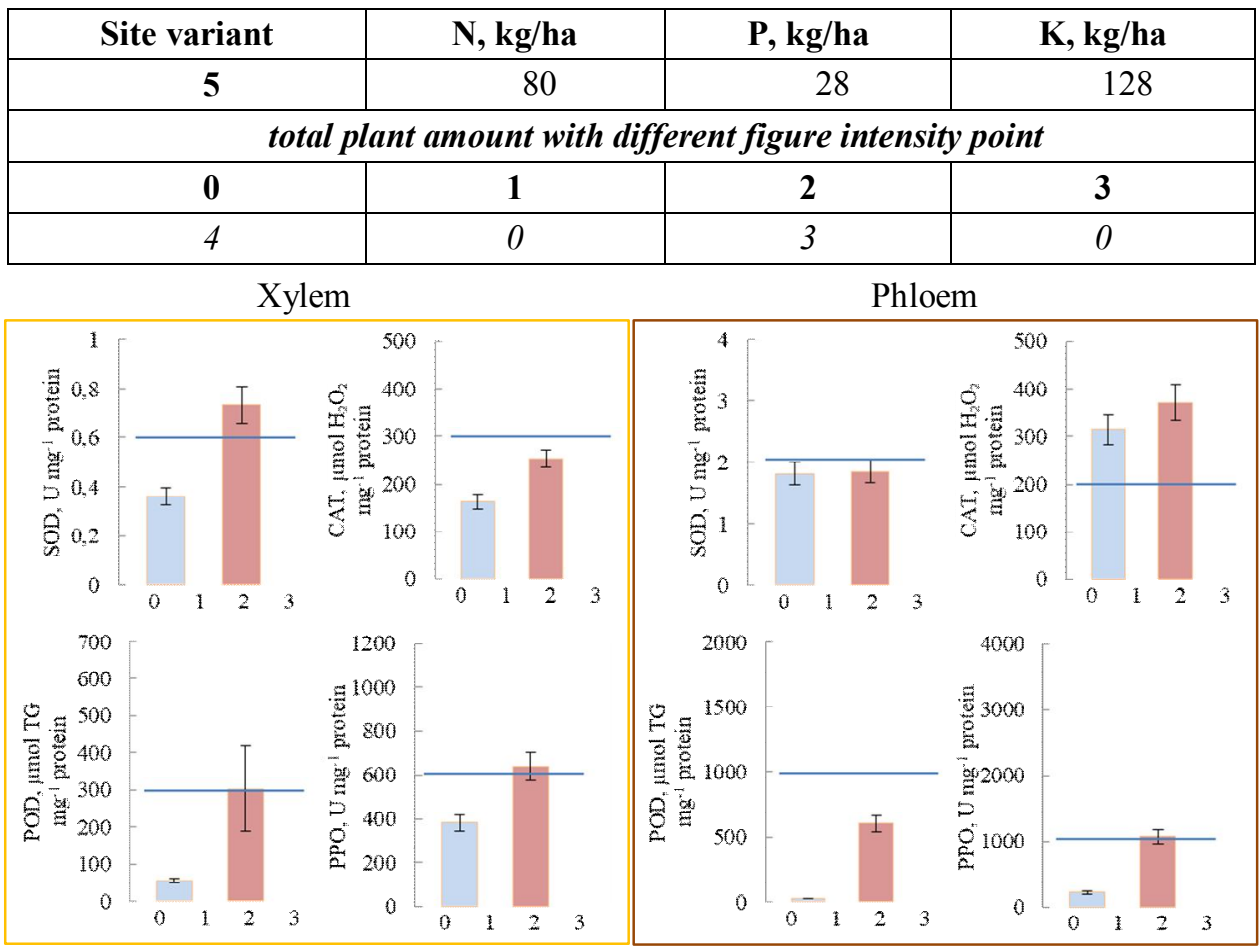

Site variant 6

\begin{tabular}{|c|c|c|c|}
\hline Site variant & $\mathbf{N}, \mathbf{k g} / \mathbf{h a}$ & $\mathbf{P}, \mathbf{k g} / \mathbf{h a}$ & $\mathbf{K}, \mathbf{k g} / \mathbf{h a}$ \\
\hline $\mathbf{6}$ & 85 & 127 & 167 \\
\hline \multicolumn{5}{|c|}{ total plant amount with different figure intensity point } \\
\hline $\mathbf{0}$ & $\mathbf{1}$ & $\mathbf{2}$ & $\mathbf{3}$ \\
\hline 1 & 2 & 2 & 2 \\
\hline
\end{tabular}

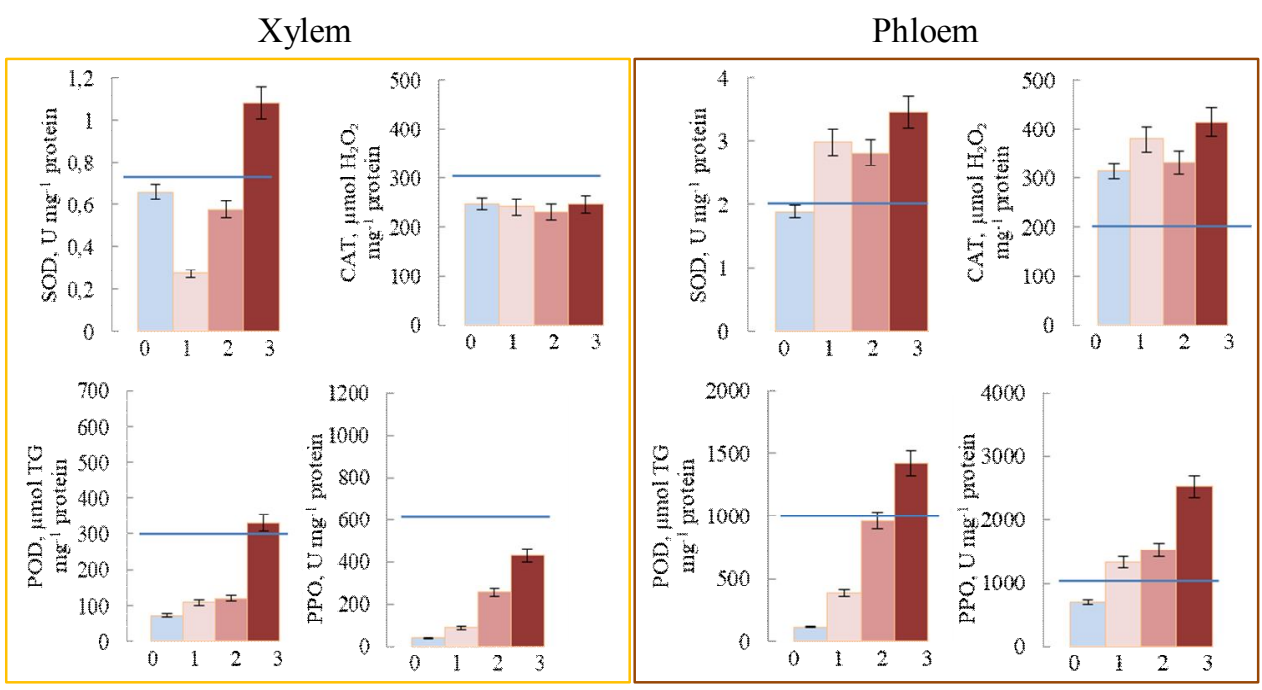


K. NIKEROVA et al.

Site variant 7

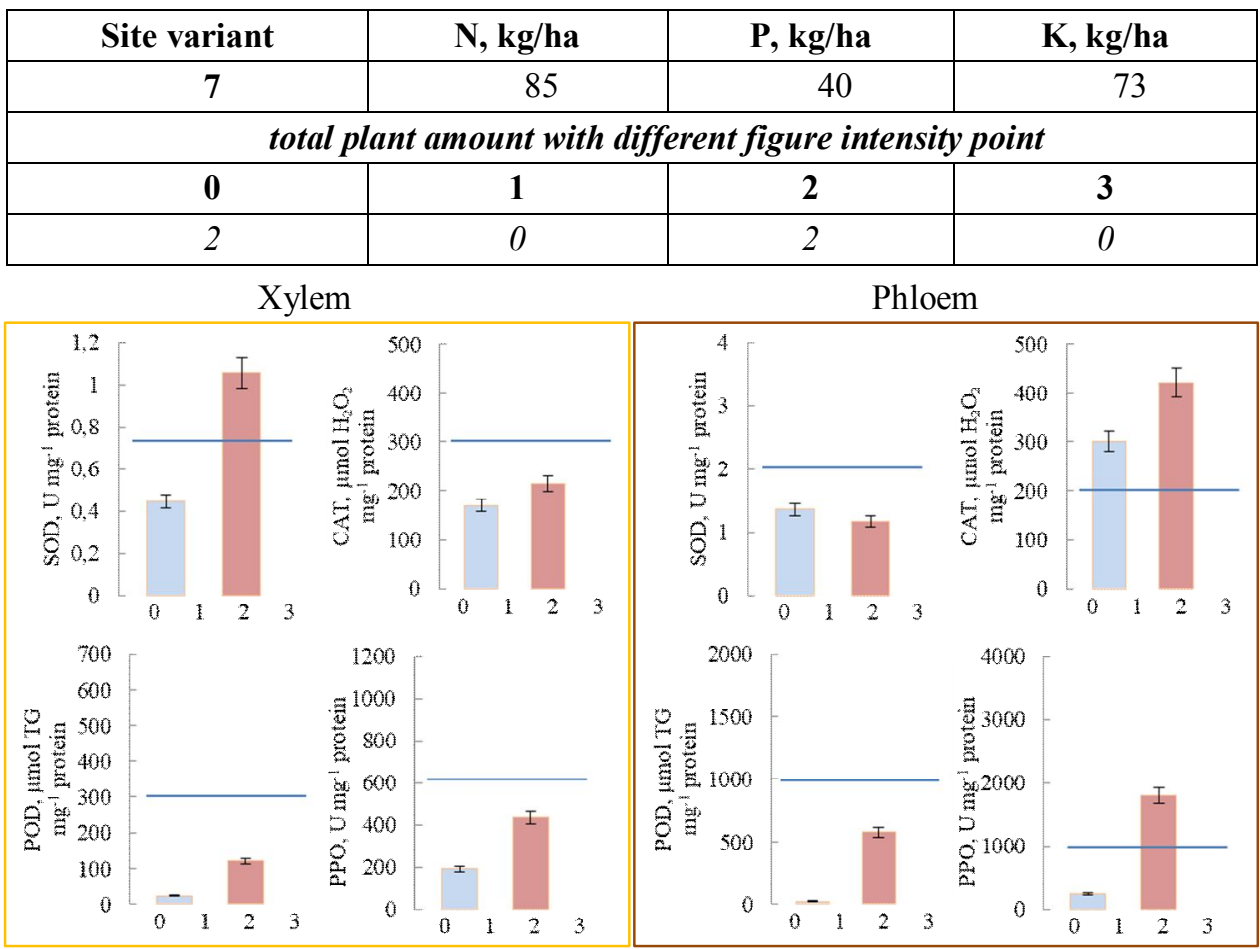

Site variant 8

\begin{tabular}{|c|c|c|c|}
\hline Site variant & $\mathbf{N}, \mathbf{~ k g} / \mathbf{h a}$ & $\mathbf{P}, \mathbf{~ k g} / \mathbf{h a}$ & $\mathbf{K}, \mathbf{~ k g} / \mathbf{h a}$ \\
\hline $\mathbf{8}$ & 108 & 124 & 138 \\
\hline \multicolumn{5}{|c|}{ total plant amount with different figure intensity point } \\
\hline $\mathbf{0}$ & $\mathbf{1}$ & $\mathbf{2}$ & $\mathbf{3}$ \\
\hline 0 & 5 & 0 & 0 \\
\hline
\end{tabular}

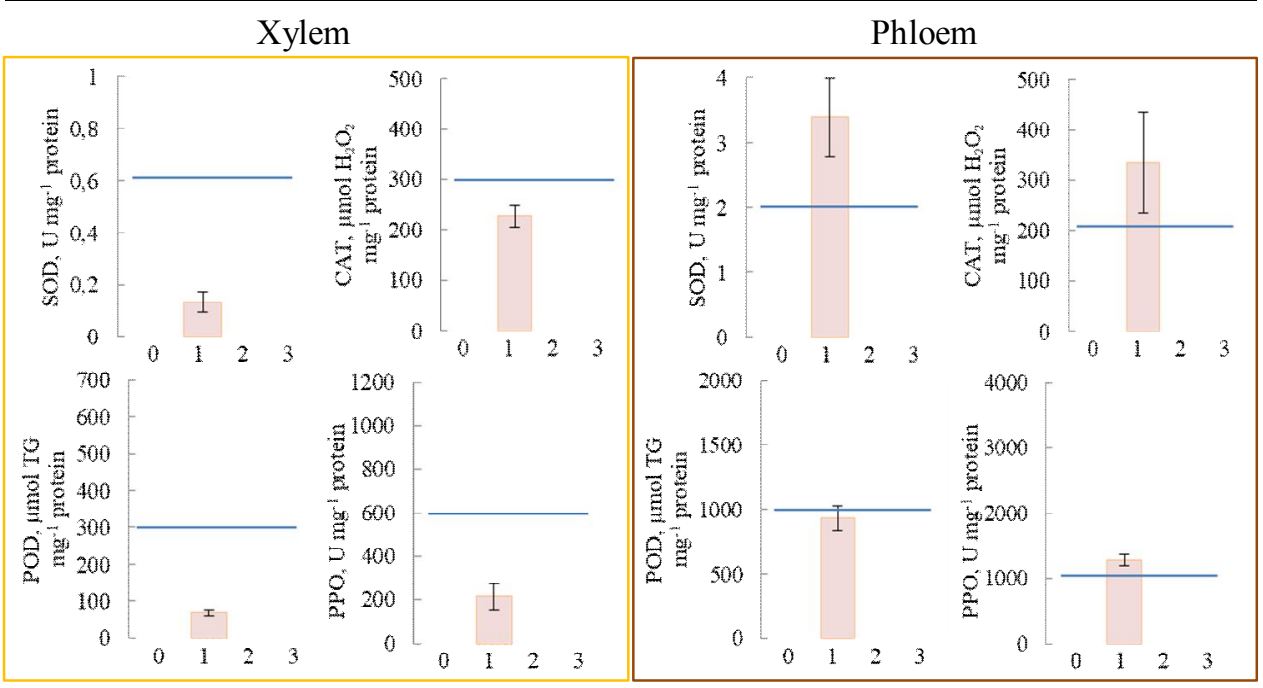




\section{Site variant 9}

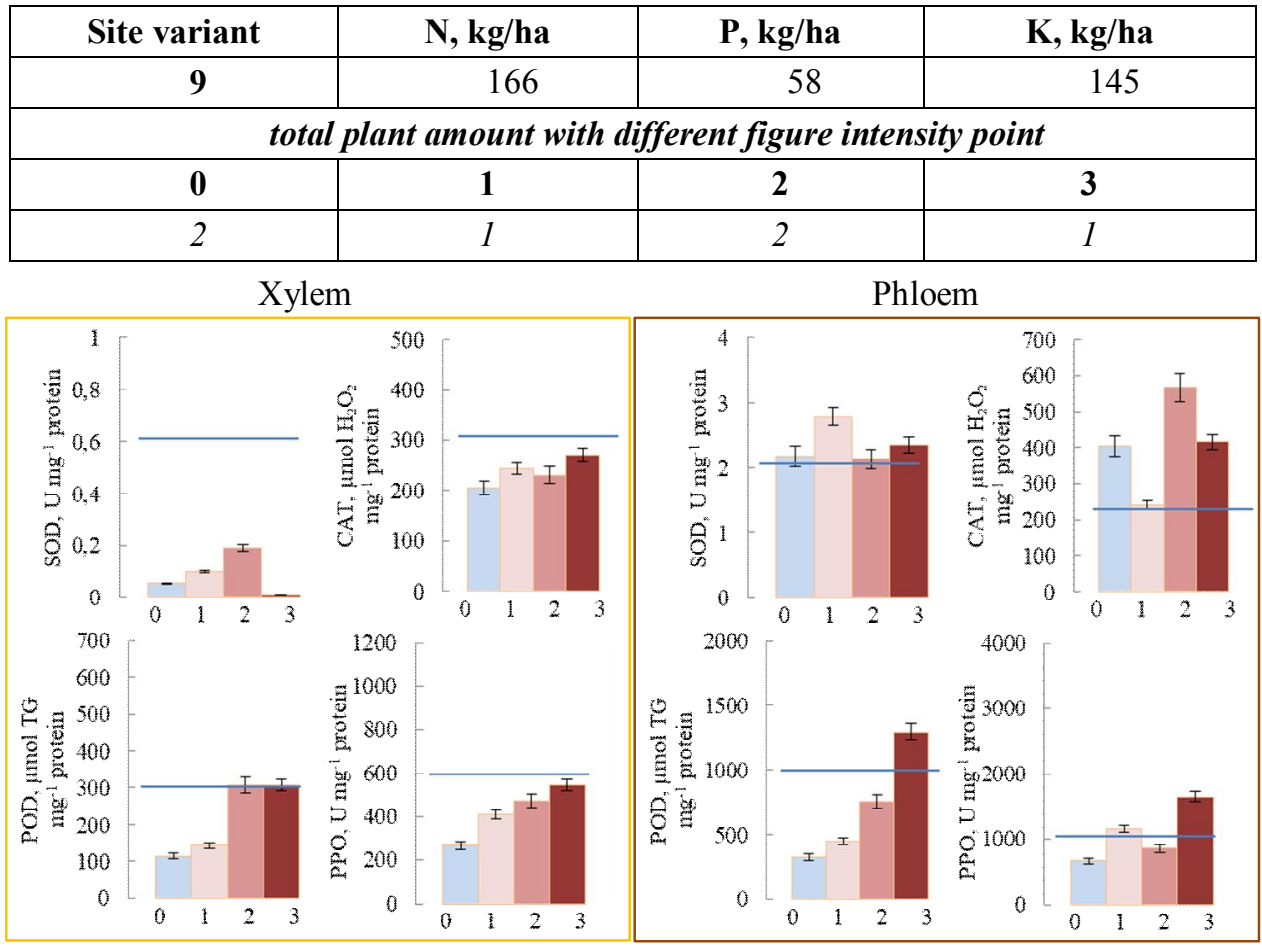

Fig. 1. The antioxidant enzymes (SOD, CAT, POD, PPO) activity in Karelian birch plants with different figured wood formation intensity point in xylem and in phloem in studied site variants.

In general, SOD activity in xylem of non-figured plants was within the range of 0.05-0.66 $\mathrm{U} \mathrm{mg}^{-1}$ protein, CAT activity 163-247 $\mu \mathrm{mol} \mathrm{H}_{2} \mathrm{O}_{2} \mathrm{mg}^{-1}$ of protein, POD activity - 18-114 $\mu \mathrm{mol} \mathrm{TG} \mathrm{mg}^{-1}$ protein, PPO activity - 39-602 $\mathrm{U} \mathrm{mg}^{-1}$ protein. SOD activity in phloem of non-figured plants was within the range of $1.3-2.2 \mathrm{U} \mathrm{mg}^{-1}$ protein, CAT activity $-110-422 \mu \mathrm{mol}$ $\mathrm{H}_{2} \mathrm{O}_{2} \mathrm{mg}^{-1}$ of protein, POD activity -21 -

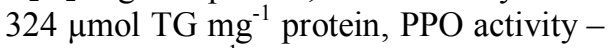
226-728 $\mathrm{U} \mathrm{mg}^{-1}$ protein. SOD activity in figured plants of all groups (xylem) was within the range of $0.04-1.1 \mathrm{U} \mathrm{mg}^{-1}$ protein, CAT activity - 188-331 $\mu \mathrm{mol}$ $\mathrm{H}_{2} \mathrm{O}_{2} \mathrm{mg}^{-1}$ of protein, POD activity 44-555 $\mu \mathrm{mol} \mathrm{TG} \mathrm{mg}^{-1}$ protein, PPO activity $-87-1075 \mathrm{U} \mathrm{mg}^{-1}$ protein. SOD activity in figured plants of all groups (phloem) was within the range of 1.2$4.2 \mathrm{U} \mathrm{mg}^{-1}$ protein, CAT activity -116 -
$851 \mu \mathrm{mol} \mathrm{H}_{2} \mathrm{O}_{2} \mathrm{mg}^{-1}$ of protein, POD

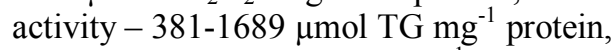
PPO activity $-861-4011 \mathrm{U} \mathrm{mg}^{-1}$ protein. It should be noted that enzymes' activities, especially PODs and PPOs, in phloem are significantly higher than in xylem. It can probably be associated with a large number of phenolic compounds in the phloem of woody plants (Antonova and Stasova 2006, 2008) and the same was shown for our objects (Nikerova et al. 2021).

Spearman's rank correlation coefficient showed that the AOS enzymes activity increased with increasing figured wood formation intensity point: in xylem SOD $(\mathrm{r}=0.66, p=0.00011)$, CAT $(\mathrm{r}=0.68$, $p<0.0001), \quad$ POD $\quad(\mathrm{r}=0.83, \quad p<0.0001)$, PPO ( $\mathrm{r}=0.66, p<0.0001)$; in phloem POD $(\mathrm{r}=0.76, p<0.0001)$, PPO $(\mathrm{r}=0.77$, $p<0.0001)$. 


\section{CAT/SOD and POD/SOD in Karelian non-figured and figured plants in xylem and phloem}

The result of SOD reaction is superoxide radicals and hydrogen peroxide formation. Hydrogen peroxide can be disposed of by CAT and POD. The coordinated work of SOD, CAT and POD occurs by maintaining a balance between superoxide radicals and hydrogen peroxide (Mittler et al. 2004, Jajic et al. 2015).

It was noted that $\mathrm{CAT} / \mathrm{SOD}$ ratio did not statistically differ in non-figured and figured plants in xylem and in phloem (Fig. 2A, 2B). It may indicate the importance and necessity of utilizing a large pool of hydrogen peroxide formed by the SOD reaction due to CAT activity. However, the tendency for the predominant role of the CAT activity of peroxide utilization was observed in non-figured plants.
We have already shown that 45-year-old non-figured plants had a great CAT role in neutralizing hydrogen peroxide throughout the season, especially in phloem tissues (Nikerova et al. 2019a).

The POD/SOD ratio was statistically higher in both xylem and phloem in figured plants, indicating a great role of POD in peroxide utilization in figured plants. Previously, it has been shown that POD activity in non-figured plants was lower in both xylem and phloem tissues than in figured plants throughout the season (Nikerova et al. 2019a). The relationship between POD and CAT activity is very interesting: the activity of one enzyme compensates for the activity of another (FernándezGarcía et al. 2004, Chen et al. 2006).

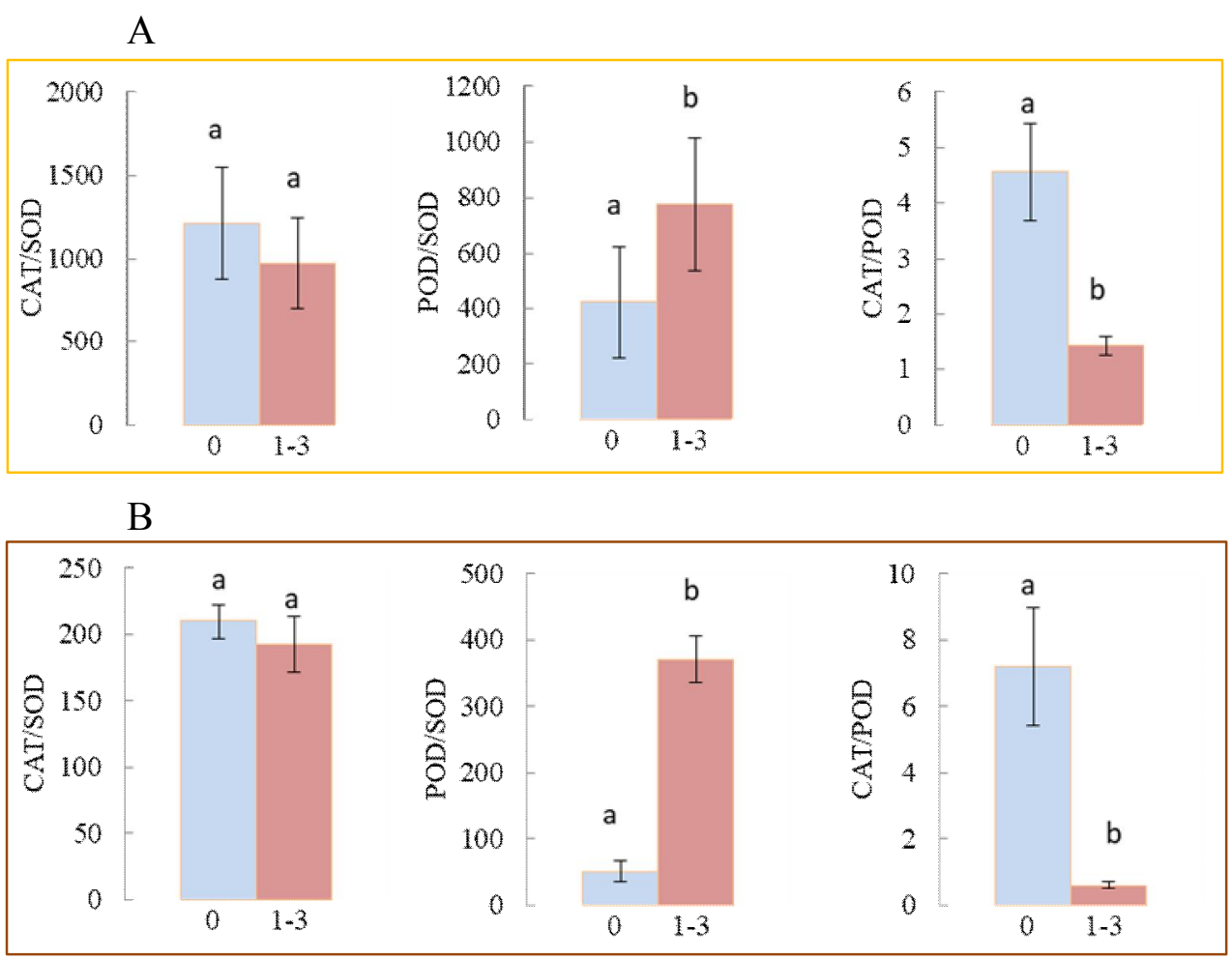

Fig. 2. $\mathrm{CAT} / \mathrm{SOD}, \mathrm{POD} / \mathrm{SOD}$, and $\mathrm{CAT} / \mathrm{POD}$ ratios in Karelian birch plants with different figured wood formation intensity point in xylem (A) and in phloem (B) in studied site variants. 
The CAT/POD ratio was also intriguing. Of course, this ratio is derived from the CAT/SOD and POD/SOD ratios, but probably because of the interconnected work of all enzymes due to the commonality of their substrates and/or reaction products (Nikerova et al. 2021), it shows the interdependence of enzyme activities within a whole antioxidant system in figured and non-figured Karelian birch plants, and the quantitative meanings of CAT/ POD ratio have minor standard errors (see
Fig. 2).

Spearman's rank correlation coefficient showed that CAT/POD ratio decreased with increasing figured wood formation intensity point: in xylem $-(\mathrm{r}=-0.65$, $p=0.00012)$ and in phloem $(\mathrm{r}=-0.73$, $p<0.00011)$. This is consistent with the previously shown indicator role of POD in Karelian birch plants with different figured wood formation intensity point (Galibina et al. 2016b, Nikerova and Galibina 2017, Nikerova et al. 2019a).

\section{The relations between major soil nutrients and the occurrence of plants with different figured wood formation intensity point in studied sites}

Major nutrients located in the soil have a great influence on each other, and therefore not only the element's content is important, but also their ratios, which were calculated on the studied sites (Table 2).

\begin{tabular}{|c|c|c|c|}
\hline Site variants & $\mathbf{P} / \mathbf{N}$ & $\mathbf{K} / \mathbf{P}$ & $\mathbf{K} / \mathbf{N}$ \\
\hline $\mathbf{1}$ & 1.8 & 1.7 & 3.0 \\
\hline $\mathbf{2}$ & 1.5 & 1.0 & 1.4 \\
\hline $\mathbf{3}$ & 0.9 & 1.4 & 1.3 \\
\hline $\mathbf{4}$ & 1.6 & 1.5 & 2.3 \\
\hline $\mathbf{5}$ & 0.4 & 4.6 & 1.6 \\
\hline $\mathbf{6}$ & 1.5 & 1.3 & 2.0 \\
\hline $\mathbf{7}$ & 0.5 & 1.8 & 0.9 \\
\hline $\mathbf{8}$ & 1.1 & 1.1 & 1.3 \\
\hline $\mathbf{9}$ & 0.3 & 2.5 & 0.9 \\
\hline
\end{tabular}

Table 2. Relations between major nutrients (available to plants) in the top 25-cm layer of soil.

Sites 2, 4, and 6, where figured plants (with figured intensity point 3 ) were found, were characterized by a similar quantitative $\mathrm{N} / \mathrm{P}$ ratio (values $1.5,1.6$ ), whereas on the site 9 this ratio was 0.3 . That meant that there was a lack of $\mathrm{P}$ in relation to $\mathrm{N}$ excess. On the site 9 enzymes' activities did not reach high values even in figured plants (with figured intensity point 3 ). K/P ratio was similar at all studied sites. But $\mathrm{K} / \mathrm{P}$ ratio on the site 5 was the highest comparing with all the studied sites. Karelian birch plants with figured intensity point 3 were found on this site, but plants with figured intensity point 2 found here had rather high values of the studied enzymes' activity comparing to all meanings. Sites 1,5 , and 7 were characterized by the absence of Karelian birch plants with figured intensity point $2 . \mathrm{K} / \mathrm{P}$ ratio on the site 1 was 1.8 , and on the site 5 and site 7 were 0.4 and 0.5 respectively. On the site 3 and site 8 , where non-figured plants and figured plants with figured intensity point 1 were found, $\mathrm{N} / \mathrm{P}$ ratio was 0.9 and 1.1 respectively. These sites can be considered intermediate among the observed ones. $\mathrm{K} / \mathrm{P}$ ratio was the least variable, among the 
considered ones $(\mathrm{P} / \mathrm{N}, \mathrm{K} / \mathrm{N})$. Two high values: 4.6 and 2.5 are interesting - on the site 5 and site 9 sites respectively. $\mathrm{K} / \mathrm{N}$ ratio also does not seem very important due to the monotonous spread of the observed quantitative values of this indicator.

Thus, it seems that $\mathrm{P} / \mathrm{N}$ ratio can have the greatest impact on the studied phenomenon for two reasons: (1) the distribution area of the Karelian birch is limited to a certain level of $\mathrm{N}$ in the soil (Novitskaya 2008); (2) it is known from the literature about the mutual influence of $\mathrm{N}$ and $\mathrm{P}$ and the importance of the ratio on the processes in woody plants. So, fertilization experiments have shown that $\mathrm{P}$ fertilizers increase survival and growth of birch seedlings when applied at the time of planting, however, only in combination with N (Ritter 2007). Past studies have generally focused on $\mathrm{N}$ because it is generally the most limiting nutrient element to plants in the field, but another key nutrient element for photosynthesis, $\mathrm{P}$ is often the most limiting or second most limiting element to the aboveground primary productivity (Danyagri and Dang 2014). The uptake and utili- zation of $\mathrm{P}$ and $\mathrm{K}$ depends on the presence of inorganic $\mathrm{N}$ compounds (Michalik 1985). Besides, our previous studies indicated, that changes in the $\mathrm{P} / \mathrm{N}$ ratio enhance the competition for photoassimilates between the processes of figured wood formation and plant growth (Galibina et al. 2019c).

The influence of major nutrients' reserves (available to plants) - nitrogen $(\mathrm{N})$, phosphorus $(\mathrm{P})$, potassium $(\mathrm{K})-$ in the top $25-\mathrm{cm}$ layer of soil and $\mathrm{P} / \mathrm{N}$ ratio on the antioxidant enzymes' activity, as well as on the enzymes' ratios (CAT/SOD, $\mathrm{POD} / \mathrm{SOD}$, and CAT/POD), which were presented above, was considered. We emphasized the fact that Spearman's rank correlation coefficient showed that the AOS enzymes' activity increased with increasing figured wood intensity point in xylem and in phloem. So if there are any correlations between soil conditions and enzymes' activity, it will lead to a preliminary conclusion about the influence of soil conditions on the wood formation intensity point, that can be expressed to a greater or lesser extent.

\section{Pearson's correlation analysis between enzymes' activities and their ratios and $\mathbf{N}$, $P, K$ reserves and the $P / N$ ratio in xylem}

Major nutrients' reserves in the soil correlate with each other. Positive correlations are noted between $\mathrm{P}$ and $\mathrm{K}$ reserves, $K$ reserve and $P / N$ ratio, and $P$ reserve and $\mathrm{P} / \mathrm{N}$ ratio. The $\mathrm{N}$ reserve and the $\mathrm{P} / \mathrm{N}$ ratio were negatively correlated (Fig. 3). These correlations confirm once again that the impact of these elements can be interrelated, and also indicates the importance of the relationship between the reserves of the major nutrients in the soil (Michalik 1985, Ritter 2007, Danyagri and Dang 2014). The sensitivity of SOD, CAT, and POD to changes in soil conditions are noted in literature (Tombesi et al. 1969, Gurgul and Herman 1994, Bourioug et al. 2014).
CAT activity increased with the increase of $\mathrm{P}$ and $\mathrm{K}$ reserves in the soil. With increasing $\mathrm{N}$ reserve, the CAT/SOD and POD/SOD ratios increased, which may indicate that with increasing soil fertility, the neutralization of the main pool of hydrogen peroxide due to CAT activity is stably maintained in the studied limit. However, the POD role in this process also increases, which may indicate an increase in the frequency of figured plants occurrence with an increase in the $\mathrm{N}$ level reserve in the soil, since POD/SOD ratio is statistically higher in figured plants (see Fig. 2). 


\section{Dependence of enzymes' activities and their ratios on nitrogen, phosphorus, and potassium reserves and the $\mathrm{P} / \mathrm{N}$ ratio in phloem}

SOD activity increased with increasing of $\mathrm{P}$ and $\mathrm{K}$ reserves in the soil. $\mathrm{K}, \mathrm{P}$ reserves, and $\mathrm{P} / \mathrm{N}$ ratio were negatively correlated with the $\mathrm{CAT} / \mathrm{SOD}$ ratio, and $\mathrm{K}$ reserve was negatively correlated with the CAT/POD ratio, which may indicate that phloem tissues do not perform the main roles in the studied processes.

Besides, substances come from the soil with xylem transport, and the functioning of the plant and transport processes oc- cur in the interconnected soil-root-xylemphloem-leaf system (Huang et al. 2018), and soil conditions affect the wood quality indirectly through processes occurring in the tree crown (Punches 2004). Thus, it was shown that there was suppression of assimilates' outflow from leaves to organsacceptors under conditions of enhanced $\mathrm{N}$ nutrition (Chikov and Bakirova 2004, Galibina et al. 2016c).

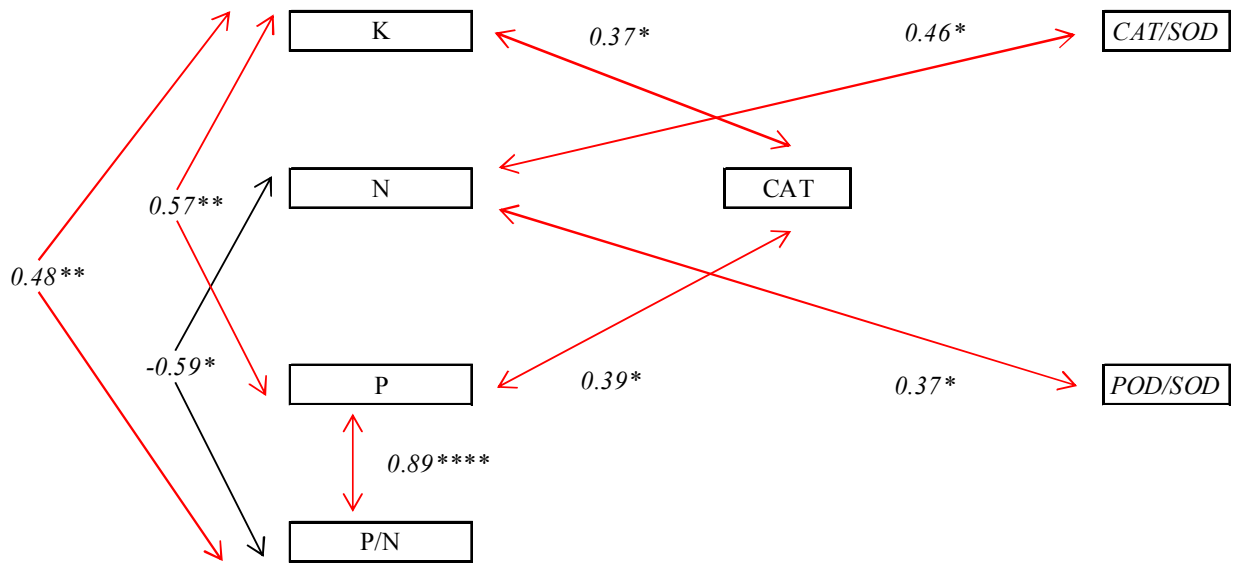

Fig. 3. Pearson's correlation analysis between enzymes' activities, their ratios and $\mathrm{N}, \mathrm{P}, \mathrm{K}$ reserves, $\mathrm{P} / \mathrm{N}$ ratio in xylem are demonstrated. Correlations are significant at $\mathrm{p} \leq 0.05(*), \mathrm{p} \leq 0.01$ $(* *), \mathrm{p} \leq 0.001(* * *), \mathrm{p} \leq 0.0001(* * *)$. Correlation coefficients are presented. Red color positive correlations, black color - negative correlations.

The system of SOD-PPO (Steffens et al. 1994, Thipyapong et al. 2004) in phloem probably plays a great role, comparing with the system of peroxide-utilizing enzymes; SOD-PPO system is aimed at unloading oxygen and ROS with the partici- pation of phenolic compounds, the content of which is higher in phloem than in xylem (Nikerova et al. 2021), although there were no statistically significant correlations between the major nutrients' reserves in the soil and PPO activity (Fig. 4). 


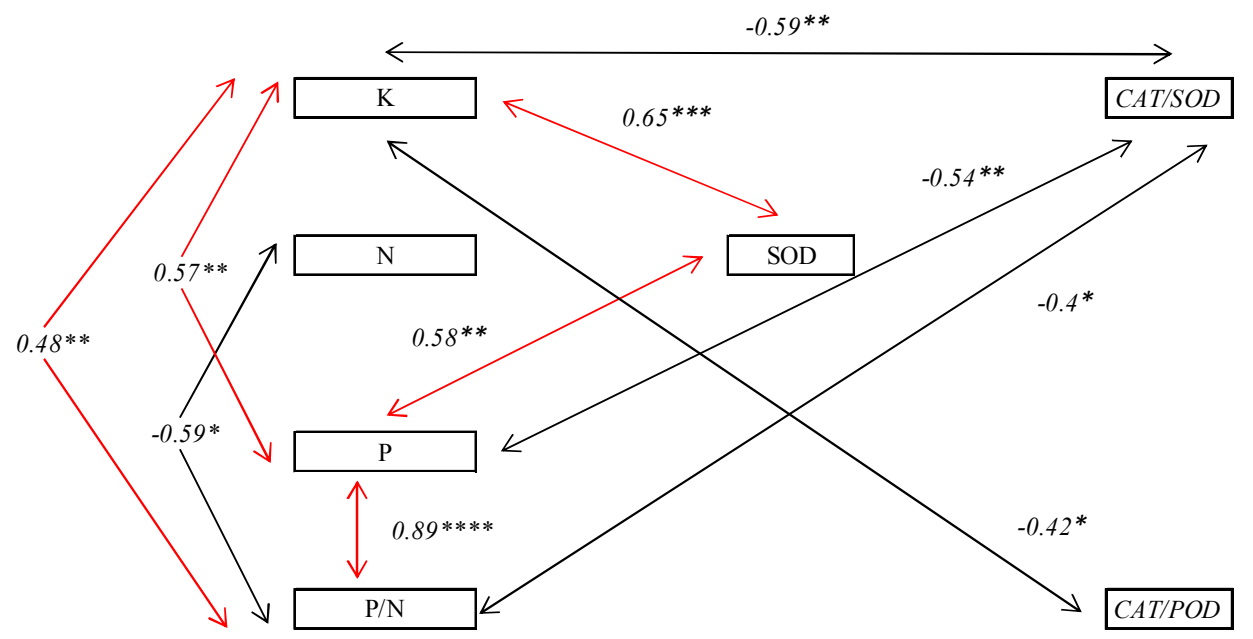

Fig. 4. Pearson's correlation analysis between enzymes' activities, their ratios and N, P, K reserves, $\mathrm{P} / \mathrm{N}$ ratio in phloem are demonstrated. Correlations are significant at $\mathrm{p} \leq 0.05\left(^{*}\right)$, $\mathrm{p} \leq 0.01(* *), \mathrm{p} \leq 0.001(* * *), \mathrm{p} \leq 0.0001(* * * *)$. Correlation coefficients are presented. Red color - positive correlations, black color - negative correlations.

\section{Dependence of lignin content and cellulose content on nitrogen, phosphorus, and potassium reserves and the $P / N$ ratio}

Previously, we showed that the cellulose content negatively correlated with the wood formation intensity point, and the highest lignin content was found in the most figured Karelian birch plants (Moschenskaya et al. 2017, Galibina et al. 2019b, Nikerova et al. 2021). Cellulose content in the studied plants was in the range of $34.6-47.5 \%$, lignin content was in the range of $-15.7-20.7 \%$. Pearson's correlation analysis showed that lignin content increased and cellulose content decreased with increasing $\mathrm{N}$ reserve (Fig. 5), lignin content decreased with increasing $\mathrm{P} / \mathrm{N}$ ratio. Besides there was negative correlation between cellulose content and lignin content in the studied plants. The literature data also emphasizes that $\mathrm{N}$ nutrition in the soil affects lignin and cellulose contents in plants (Harding et al. 2009), as was shown under molecular level also (Pitre et al. 2010).

Interestingly, the highest lignin content $(20.7 \%)$ was found in figured plants (with figured intensity point 3 ) growing on the site 9 with the highest $\mathrm{N}$ reserve level in the soil, while the same plants had the lowest cellulose content among the studied plants $(34.6 \%)$. On the contrary, the lowest lignin content $(15.7 \%)$ was detected in nonfigured from the site 1, while they had the highest cellulose content (47.5\%) (Fig. 5).

We investigated the effect of exogenous nitrate on SS, ApInv, POD activities in the trunks of silver birch and Karelian birch during cambial growth (Galibina et al. 2016a, Nikerova and Galibina 2017). In silver birch, nitrate application increased sucrose utilization by SS, promoting wood growth, and it did not affect the POD activity. In Karelian birch xylem, nitrates led to a decrease in SS, ApInv and POD activities. This resulted in a decrease in wood growth (caused by SS decline) and a decrease in the amount of parenchyma, i.e. normalization of the wood structure (caused by ApInv decline). 

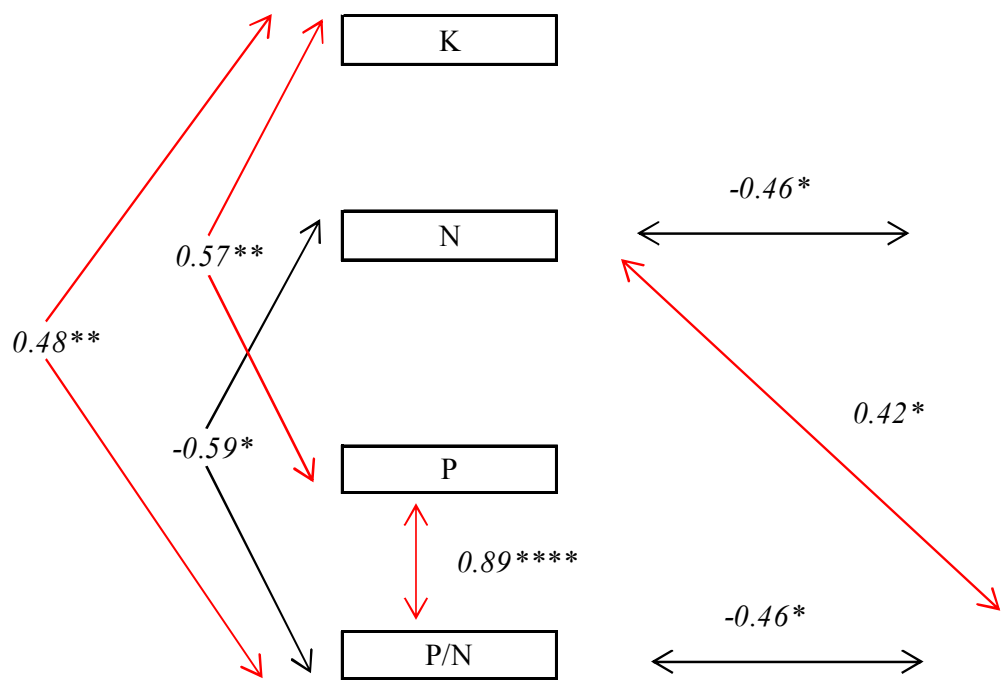

cellulose

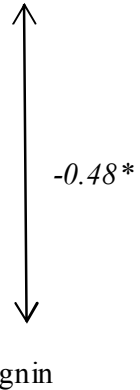

Fig. 5. Pearson's correlation analysis between lignin content and cellulose content and $N, P, K$ reserves, $\mathrm{P} / \mathrm{N}$ ratio in phloem are demonstrated. Correlations are significant at $\mathrm{p} \leq 0.05\left(^{*}\right)$, $\mathrm{p} \leq 0.01(* *), \mathrm{p} \leq 0.001(* * *), \mathrm{p} \leq 0.0001(* * *)$. Correlation coefficients are presented. Red color - positive correlations, black color - negative correlations.

Exogenous nitrate application led to a change in the donor-acceptor relationships, which also affected the activities of SS, ApInv and POD both in birch trees of different forms, and in seedlings (Galibina et al. 2016c, Moshchenskaya and Nikerova 2016, Nikerova and Galibina 2017). An increase in the acceptor role of the leaf apparatus was observed in the studied plants.

Previously, we showed that exogenous nitrate application was accompanied by POD activity increase in xylem and especially in the phloem in Karelian birch plants, which indicated an increase in free sucrose in these tissues. Normal phloem transport is possible only if a relatively low level of sucrose is maintained in the unloading zone, which was observed in silver non-figured birch (Novitskaya et al. 2015). Additional mechanisms of sucrose utilization are activated: the starch, tannins synthesis, sclerification of the parenchyma in the immediate nearness of the cambium under a high sucrose concentration in the sieve tubes and parenchymal cells of the conducting phloem. As a result, the cells in the cambial zone, which should have lost the protoplast, save it and change into cells of the storage parenchyma (Novitskaya 2008). Nitrate $N$ application aggravates these processes in the Karelian birch. This is probably why birches that grow on fertile soils are described as forming thick bark, and as a result, forms of birch with rough bark appear (Novitskaya 2008). It was also previously established that in the xylem tissues of Karelian birch, the rigidity of the cell wall structure is higher compared to silver birch with non-figured wood due to an increase in the proportion of phenolic components both in the composition of lignin and in the cross feruloyl bridges (Galibina and Terebova 2014). Then it seems logical that the results of present study showed the most intensive lignin synthesis under the highest $\mathrm{N}$ level of in the soil. 


\section{Conclusion}

One of the aspects of understanding the ecological and physiological mechanisms of xylogenesis regulation is the study of the relationship between soil conditions and the of the wood characteristics. In order to be able to influence this aspect, a detailed study of the studied plants growing sites and the choice of diagnostic parameters that could characterize a particular xylogenesis way occurring in specific conditions is necessary. After that, it is important to search for relationships between soil conditions and selected diagnostic parameters. The analysis of literature and the results of present study showed a great difficulty and complexity of studies of these xylogenesis aspects.

The present study showed that the major nutrients' reserves in the soil, especially $\mathrm{N}$ and $\mathrm{P} / \mathrm{N}$ ratio even in a narrow range of nutrients' changes, affect the occurrence of plants with different degrees of figured wood intensity, as well as wood quality, which may be dominated by the cellulose or lignin synthesis. The AOS enzymes' activity of in trunk tissues, which has an indicator value in abnormal Karelian birch xylogenesis, is not the same in different sites. There is no doubt that further research is necessary for clear conclusions.

\section{References}

Agrawal, S. B., Rathore, D. (2007): Changes in oxidative stress defense system in wheat (Triticum aestivum L.) and mung bean (Vigna radiata L.) cultivars grown with and without mineral nutrients and irradiated by supplemental ultraviolet-B. Environmental and Experimental Botany, 59(1): 21-33.

Albert, K. R., Mikkelsen, T. N., Ro-Poulsen, H., Arndal, M. F. and Michelsen, A. (2011): Ambient UV-B radiation reduces PSII performance and net photosynthesis in high Arctic Salix arctica. Environmental and Experimental Botany, 73: 10-18.

AlPERT, P. (2006): Constraints of tolerance: Why are desiccation-tolerant organisms so small or rare? Journal of Experimental Biology, 209(9): 1575-1584.

Amor, Y., Haigler, C. H., Johnson, S., Wainscott, M. and Delmer, D. P. (1992): A membraneassociated form of sucrose synthase and its potential role in synthesis of cellulose and callose in plants. Proceedings of the National Academy of Sciences USA, 92(20): 53-57.

Antonova, G. F., Stasova, V. V. (2006): Seasonal development of phloem in Scots pine stems. Russian Journal of Developmental Biology, 37(5): 306-320.

Antonova G. F., Stasova V. V. (2008): Seasonal development of phloem in Siberian larch stems. Russian Journal of Developmental Biology, 39(4): 207-218.

BATASHEVA, S.N. (2006): Nitrate ion in apoplast of plants: Effect on photosynthesis and assimilate transport. Dissertation, Kazan. 168 p. (In Russian).

Bazilevich, N. I., Titlyanova, A. A. (2008): Biological turnover on five continents: Nitrogen and ash elements in natural terrestrial ecosystems. Publishing House of Siberian Branch of the Russian Academy of Sciences, Novosibirsk, 380 p.

BeEts, P. N., Gilchrist, K. and JefFreys, M. P. (2001): Wood density of radiata pine: Effect of nitrogen supply. Forest Ecology and Management, 45(3): 173-180.

Borges, C. V., Minatel, I. O., Gomez-Gomez, H. A. and Lima, G. P. P. (2017): Medicinal Plants: Influence of environmental factors on the content of secondary metabolites. In: M. Ghorbanpour, A. Varma (eds.): Medicinal Plants and Environmental Challenges, Cham, Springer, pp. 259-278.

Bourioug, M., Alaoui-Sossé, L., Laffray, X., Raouf, N., Benbrahim, M., Badot, P. M. and AlaOUI-Sossé, B. (2014): Evaluation of sewage sludge effects on soil properties, plant growth, mineral nutrition state, and heavy metal distribution in European larch seedlings (Larix decidua). Arabian Journal for Science and Engineering, 39(7): 5325-5335. 
Bruskova, R. K., Nikitin, A. V., Satskaya, M. V. and Izmailov, S. F. (2009): Effect of nitrate on pea sucrosesynthase. Russian Journal of Plant Physiology, 56(1): 74-79.

ChalKer-ScotT, L., ScotT, J. D. (2004): Elevated ultraviolet-B radiation induces cross-protection to cold in leaves of Rhododendron under field conditions. Photochemistry and Photobiology, 79(2): 199-204.

CHEN, Y., ZhANG, M., Chen, T., ZhANG, Y. and AN, L. (2006): The relationship between seasonal changes in anti-oxidative system and freezing tolerance in the leaves of evergreen woody plants of Sabina. South African Journal of Botany, 72(2): 272-279.

Chikov, V. I., Avvakumova, N. Yu. and Bakirova, G. G. (2003): Postphotosynthetic utilization of labeled assimilates in fiber flax. Biology Bulletin, 30(4): 377-382.

Chikov, V. I., BAKIROVA, G. G. (2004): Role of the apoplast in the control of assimilate transport, photosynthesis and plant productivity. Russian Journal of Plant Physiology, 51(3): 420-431.

CoueE, I., Sulmon, C., GouesBet, G. and El AmRANI, A. (2006): Involvement of soluble sugars in reactive oxygen species balance and responses to oxidative stress in plants. Journal of Experimental Botany, 57(3): 449-459.

Cown, D. J. (1974): Wood density of radiata pine its variation and manipulation. New Zealand Journal of Forestry, 19(1): 84-92.

Dani, V., Simon, W. J., Duranti, M. and Croy, R. R. (2005): Changes in the tobacco leaf apoplast proteome in response to salt stress. Proteomics, 5(3): 737-745.

DANYAGRI, G., DANG, Q. L. (2014): Effects of elevated carbon dioxide concentration and soil temperature on the growth and biomass responses of mountain maple (Acer spicatum) seedlings to light availability. Journal of Plant Ecology, 7(6): 535-543.

DÜNISCH, O., BAUCH, J. (1994): Influence of soil substrate and drought on wood formation of spruce (Picea abies [L.] Karst.) under controlled conditions. Holzforschung, 48(6): 447-457.

ERICSON, B. (1966): Gallringens inverkan på vedens torr-råvolymvikt, höstvedhalt och kärnvedhalt hos tall och gran. Skogshögskolan. Institutionen för skogsproduktion. Rapporter och Uppsatser $N r ., 10: 1-116$.

FernÁNdez, M. P., Norero, A., Vera, J. R. and PÉrez, E. (2011): A functional-structural model for radiata pine (Pinus radiata) focusing on tree architecture and wood quality. Annals of Botany, 108(6): 1155-1178.

Fernández-García, N., Carvajal, M. and Olmos, E. (2004): Graft union formation in tomato plants: Peroxidase and catalase involvement. Annals of Botany, 93(1): 53-60.

Foucart, C., Paux, E., Ladouce, N., San-Clemente, H., Grima-Pettenati, J. and Sivadon, P. (2006): Transcript profiling of a xylem vs phloem cDNA subtractive library identifies new genes expressed during xylogenesis in Eucalyptus. New Phytology, 170(4): 739-752.

FuJII, S., HAYASHI, T. and MizunO, K. (2010): Sucrose synthase is an integral component of the cellulose synthesis machinery. Plant and Cell Physiology, 51(2): 294-301.

Galibina, N. A., Terebova, E. N. (2014): Physical-chemical properties of Betula pendula Roth trunk tissue cell walls. Proceedings of Petrozavodsk state, 4: 19-24.

Galibina, N. A., Novitskaya, L. L., Krasavina, M. S. and Moshchenskaya, Yu. L. (2015a): Activity of sucrose synthase in trunk tissues of Karelian birch during cambial growth. Russian Journal of Plant Physiology, 62(3): 381-389.

Galibina, N. A., Novitskaya, L. L., Krasavina, M. S., Moshchenskaya, Yu. L. (2015b): Invertase activity in trunk tissues of Karelian birch. Russian Journal of Plant Physiology, 62(6): 804-813.

Galibina, N. A., Novitskaya, L. L. and Nikerova, K. M. (2016a): Excess of exogenous nitrates inhibits formation of abnormal wood in the Karelian birch. Russian Journal of Developmental Biology, 47(2): 69-76.

Galibina, N. A., Moshinina, E. V., Nikerova, K. M., Moshchenskaya, Yu. L. and Znamenskit, S. R. (2016b): Peroxydase activity indicates veining of curly birch. Lesovedenie, 4: 294-304. (In Russian).

Galibina, N. A., Novitskaya, L. L. and Sofronova I. N. (2016c): Application of nitrate nitrogen enhances the source function of leaves in Karelian birch. International Journal of Applied and Fundamental Research, 10(4): 582-586. 
Galibina, N. A., Novitskaya, L. L. and Nikerova, K. M. (2019a): Source-sink relations in the organs and tissues of silver birch during different scenarios of xylogenesis. Russian Journal of Plant Physiology, 66(2): 308-315.

Galibina, N. A., Novitskaya, L. L., Nikerova, K. M., Moshchenskaya, Yu. L., Borodina, M. N. and Sofronova, I.N. (2019b): Apoplastic invertase activity regulation in the cambial zone of Karelian birch. Russian Journal of Developmental Biology, 50(1): 20-29.

Galibina, N. A., Novitskaya, L. L., Nikerova, K. M., Moshina, E. V., Moshchenskaya, Yu. L., Borodina, M. N., Sofronova, I. N. and Nikolaeva, N. N. (2019c): Labile nitrogen availability in soil influences the expression of wood pattern in Karelian birch. Botanicheskii Zhurnal, 104(10): 101-112.

GELES, I. S. (2001): Drevesnaja biomassa I osnovyj ekologicheskipriemlemyh tehnologijee himikomehanicheskoj pererabotki. KarNC RAN, Petrozavodsk, 382 p. (In Russian).

Gordon, A. J., Minchin, F. R., James, C. L. and Komina, O. (1999): Sucrose synthase in legume nodules essential for nitrogen fixation. Plant Physiology, 120(3): 867-877.

Gordon, A. J., Sкот, L., JAmeS, C. L. and Minchin, F. R. (2002): Short term metabolic responses of soybean root nodules to nitrate. Journal of Experimental Botany, 53(368): 423-428.

Gurgul, E., Herman, B. (1994): Influence of nitrogen, phosphorus and potassium on chemical composition and activity of some enzymes in celery during its growth. Biologia Plantarum, 36(2): 261-265.

HAKKILA, P. (1966): Investigations on the basic density of Finnish pine, spruce and birch wood. Communicationes Instituti Forestalis Fenniae, 61(5): 1-98.

HAKKIla, P. UusvaARA, O. (1968): On the basic density of plantation-grown Norway spruces. Communicationes Instituti Forestalis Fenniae, 66(6): 1-23.

HARDing, S.A., JARVIE, M. M., LindRoth, R. L. and TsAi, C. J. (2009): A comparative analysis of phenylpropanoid metabolism, $\mathrm{N}$ utilization, and carbon partitioning in fast- and slow-growing Populus hybrid clones. Journal of Experimental Botany, 60: 3443-3452.

HARRIS, J. M., MCCONCHIE, D. L. and PoveY, W. A. (1978): Wood properties of clonal radiata pine grown in soils with different levels of available nitrogen, phosphorus and water. New Zealand Journal of Forestry Science, 8(3): 417-430.

Hideg, É., Rosenqvist, E., VÁradi, G., BornMAN, J. and Vincze, É. (2006): A comparison of UVB induced stress responses in three barley cultivars. Functional Plant Biology, 33(1): 77-90.

HidEG, É., VASS, I. (1996): UV-B induced free radical production in plant leaves and isolated thylakoid membranes. Plant Science, 115(2): 251-260.

Hoermiller, I. I., Naegele, T., Augustin, H., Stutz, S., Weckwerth, W. and Heyer, A. G. (2017): Subcellular reprogramming of metabolism during cold acclimation in Arabidopsis thaliana. Plant, Cell \& Environment, 40(5): 602-610.

Hu, M., Shi, Z., Zhang, Z. and Zhang, Y., Li, H. (2012): Effects of exogenous glucose on seed germination and antioxidant capacity in wheat seedlings under salt stress. Journal of Plant Growth Regulation, 68(2): 177-188.

Huang, C. W., Domec, J. C., Palmroth, S., Pockman, W. T., Litvak, M. E. and Katul, G. G. (2018): Transport in a coordinated soil-root-xylem-phloem leaf system. Advances in Water Resources, 119: 1-16.

IAKIMOVA, E. T., Woltering, E. J. (2017): Xylogenesis in zinnia (Zinnia elegans) cell cultures: unraveling the regulatory steps in a complex developmental programmed cell death event. Planta, 245(4): 681-705.

Jajic, I., SARna, T. and Strzalka, K. (2015): Senescence, stress, and reactive oxygen species. Plants, 4(3): 393-411.

JalaVA, M. (1933): Suomalaisen männyn lujuusominaisuuksista. Communicationes Instituti Forestalis Fenniae, 18(7): 1-187.

Jansen, M. A., Hectors, K., O’Brien, N. M., Guisez, Y. and Potters, G. (2008): Plant stress and human health: Do human consumers benefit from UV-B acclimated crops? Plant Science, 175(4): 449-458.

JANSEN, M. A., Hideg, É. and Lidon, F. J. (2012): UV-B radiation: when does the stressor cause stress? Emirates Journal of Food and Agriculture, 24(6): 1-5. 
JAYNE, B. A. (1958): Effect of site and spacing on the specific gravity of wood of plantation grown red pine. Tappi, 41(4): 162-166.

KALBINA, I., StRID, $\AA$. (2006): The role of NADPH oxidase and MAP kinase phosphatase in UVB-dependent gene expression in Arabidopsis. Plant, Cell \& Environment, 29(9): 1783-1793.

KÄRKKÄINEN, M. DumELl, O. (1983): Kuusipuun taivutuslujuuden riippuvuus tiheydestä ja vuosiluston leveydestä Etelä-ja Pohjois-Suomessa. Silva Fennica, 17(2): 123-135.

KLEM, G. G. (1957). The quality of Norway spruce (Picea abies) of Norwegian and German origin. Meddeland Norske Skogforsoksv, 14: 285-315.

KuBLER, H. (1991): Function of spiral grain in trees. Trees, 5(3): 125-135.

KuHN, A. J., SCHRÖDER, W. H. and BAUCH, J. (1997): On the distribution and transport of mineral elements in xylem, cambium and phloem of spruce (Picea abies [L.] Karst.). HolzforschungInternational Journal of the Biology, Chemistry, Physics and Technology of Wood, 51(6): 487496.

KÜRSCHNER, K., HOFFER, A. (1929): Ein neues verfahren zur bestimmung der cellulose in hölzern und zellstoffen. Tech. Chem. Pap. Zellst. Fabr., 26: 125-129.

Lassila, J. (1931): Untersuchungen fiber den Eintluss des Waldtyps auf die Qualitit der Kiefer. Acta Forestalia Fennica, 37: 5.

Li, X., ZhANG, L., LI, Y., MA, L., Bu, N. and MA, C. (2012): Changes in photosynthesis, antioxidant enzymes and lipid peroxidation in soybean seedlings exposed to UV-B radiation and/or Cd. Plant and Soil, 352(1-2): 377-387.

Michalik, H. (1985): Effect of fertilization by macro and microelements on the content of dry matter, saccharides and carotene in carrot. Biuletyn Warzywniczy, 28: 141-165. (In Polish).

Mittler, R., Vanderauwera, S., Gollery, M. and Van Breusegem, F. (2004): Reactive oxygen gene network of plants. Trends Plant Science, 9(10): 1360-1385.

Moshchenskaya, Yu. L., Nikerova, K. M. (2016): Activity of sucrose dissimilating enzymes in early ontogeny in different forms of silver birch. Trans KarRC RAS, 11: 78-87. (In Russian).

Moshchenskaya, Yu. L., Galibina, N. A., Topchieva, L. V. and Novitskaya, L. L. (2017): Expression of genes encoding sucrose synthase isoforms during anomalous xylogenesis in Karelian birch. Russian Journal of Plant Physiology, 64(4): 616-624.

Moshchenskaya, Yu. L., Galibina, N. A., Novitskaya, L. L. and Nikerova, K. M. (2019): The role of sucrose synthase in sink organs of woody plants. Russian Journal of Plant Physiology, 66(1): 10-21.

MoYA, R., PÉREZ, D. (2008): Effects of physical and chemical soil properties on physical wood characteristics of Tectona grandis plantations in Costa Rica. Journal of Tropical Forest Science, 20(4): 248-257.

NAWROT, M., PAZDROWSKI, W. and SZYMAŃSKI, M. (2008): Dynamics of heartwood formation and axial and radial distribution of sapwood and heartwood in stems of European larch (Larix decidua Mill.). Journal of Forest Science, 54(9): 409-417.

Nikerova, K. M., Galibina, N. A. (2017): The influence of nitrate on the peroxidase activity in tissues of Betula pendula Roth var. pendula and B. pendula var. carelica (Mercklin). Siberian Journal Forest Science, 1: 15-24. (In Russian).

Nikerova, K. M., Galibina, N. A., Moshchenskaya, Yu. L., Novitskaya, L. L., Podgornaya, M. N. and Sofronova, I. N. (2018): The antioxidant enzymes - indicators of different xylogenesis scenarios: in early ontogeny and in adult plants (example of Betula pendula Roth). Trans KarRC RAS, 11: 78-87. (In Russian).

Nikerova, K. M., Galibina, N. A., Moshchenskaya, Yu. L., Novitskaya, L. L., Podgornaya, M. N. and Sofronova, I. N. (2019a): Contribution of catalase and peroxidase to xylogenesis of Karelian birch. Lesovedenie, 2: 115-127. (In Russian).

Nikerova, K. M., Galibina, N. A., Moshchenskaya, Yu. L., Novitskaya, L. L., Podgornaya, M. N. and Sofronova, I. N. (2019b): Determination of superoxide dismutase and polyphenol oxidase activity in Betula pendula var. carelica (Betulaceae) wood with different degree of xylogenesis disturbance. Rastitelnye Resursy, 55(2): 213-230. (In Russian). 
Nikerova, K., Galibina, N., Moshchenskaya, Yu., Borodina, M., Sofronova, I. and NOVITSKAYA, L. (2021, unpublished; under review): The antioxidant system enzymes activity increase as a biochemical indicator of Karelian birch abnormal xylogenesis. Trees.

Nikitin, A. V., Bruskova, R. K., Andreeva, T. M. and Izmailov, S. F. (2010): Effect of ammonia on sucrose synthase in pea roots Pisum sativum L. Russian Journal Plant Physiology, 57(1): 76-80.

Nikitin, A. V., Izmailov, S. F. (2016): Enzymes of sucrose dissimilation as targets for nitrate in early ontogenesis of garden pea. Russian Journal of Plant Physiology, 63(1): 152-157.

Nomura, T., Shiozawa, M., Ogita, S. and Kato, Y. (2013): Occurrence of hydroxycinnamoyl putrescines in xylogenic bamboo suspension cells. Plant Biotechnology, 30(5): 447-453.

NovitskayA, L. L. (2008): Karelian birch: Mechanisms of growth and development of structural abnormalities. Publishing House Verso, Petrozavodsk, 144 p. (In Russian).

NovitskayA, L. L., KushNiR, F. V. (2006): The role of sucrose in regulation of trunk tissue development in Betula pendula Roth. Journal of Plant Growth Regulation, 25: 18-29.

Novitskay A, L. L., Galibina, N. A. and Nikerova, K. M. (2015): Sugar transport and storage in the phloem of Betula pendula Roth var. pendula and var. carelica. Transactions of the Karelian Research Centre of the Russian Academy of Sciences. Experimental Biology Series, 11: 35-47. (In Russian).

Novitskaya, L., Nikolaeva, N., Galibina, N., Tarelkina, T. and Semenova, L. (2016): The greatest density of parenchyma inclusions in Karelian birch wood occurs at confluences of phloem flows. Silva Fennica, 50(3): 1461-1478.

Novitskaya, L. L., Shulyakovskaya, T. A., Galibina, N. A. and Ilyinova, M. K. (2018): Membrane lipid composition upon normal and patterned wood formation in Betula pendula Roth. Journal of Plant Growth Regulation, 37(3): 958-970.

Novitskaya, L. L., Tarelkina, T. V., Galibina, N. A., Moshchenskaya, Y.L., Nikolaeva, N. N., Nikerova, K. M., Podgornay a, M. N., Sofronova, I. N. and Semenova, L. I. (2020): The formation of structural abnormalities in Karelian birch wood is associated with auxin inactivation and disrupted basipetal auxin transport. Journal of Plant Growth Regulation, 39(1): 378-394.

Obolenskaya, A. V., Elnitskaya, Z. P. and LeOnovich, A. A. (1991): Laboratory works on chemistry of wood and cellulose. Ekologiya, Moscow, 1991, 320 p. (In Russian).

Paul, B. H. (1950): Wood quality in relation to site quality of second-growth Douglas-Fir. Journal of Forestry, 48(3): 175-179.

PaUL, B. H. (1959) The effect of environmental factors on wood quality. Gen Tech Rep FPL US For Prod Lab Madison, pp. 1-47.

Pitre, F. E., Lafarguette, F., Boyle, B., Pavy, N., Caron, S., Dallaire, N. and Ly Lim, E. (2010): High nitrogen fertilization and stem leaning have overlapping effects on wood formation in poplar but invoke largely distinct molecular pathways. Tree Physiology, 30(10): 1273-1289.

Pokharel, B., Dech, J. P., Groot, A. and Pitt, D. (2014): Ecosite-based predictive modeling of black spruce (Picea mariana) wood quality attributes in boreal Ontario.Canadian Journal of Forest Research, 44(5): 465-475.

Punches, J. (2004): Tree growth, forest management, and their implications for wood quality. https://catalog.extension.oregonstate.edu/sites/catalog/files/project/pdf/pnw576.pdf

Rikala, J. (2003): Spruce and pine on drained peatlands $\mho$ wood quality and suitability for the sawmill industry. University of Helsinki, Department of Forest Resource Management, 35: 147.

RitTER, E. (2007): Carbon, nitrogen and phosphorus in volcanic soils following afforestation with native birch (Betula pubescens) and introduced larch (Larix sibirica) in Iceland. Plant and Soil, 295(1-2): 239-251.

Robertson, D., BEECH, I. and Bolwell, G. P. (1995): Regulation of the enzymes of UDP-sugar metabolism during differentiation of French bean. Phytochemistry, 39(1): 21-28.

RuAN, Y. L., LLEWELLyn, D. J. and FuRBANK, R. T. (2003): Suppression of sucrose synthase gene expression repressescotton fiber cell initiation, elongation, and seed development. The Plant Cell Online, 15(4): 952-964. 
SARANPÄÄ, P. (1983): Puuaineen tiheyden ja vuosiluston leveyden vaikutus kuusen iskutaivutuslujuuteen Etelä-ja Pohjois-Suomessa. Silva Fennica, 17(4): 381-388.

SAVIDGE, R. A. (1996): Xylogenesis, genetic and environmental regulation. JAWA Journal, 17(3): 269-310.

Sin'KeVICH, M. S., DeRYABIN, A. N. and TrunOVA, T. I. (2009): Characteristics of oxidative stress in potato plants with modified carbohydrate metabolism. Russian Journal of Plant Physiology, 56(2): 168-174.

Solheim, B., Johanson, U., Callaghan, T. V., Lee, J. A., Gwynn-Jones, D. and BJöRn, L. O. (2002): The nitrogen fixation potential of arctic cryptogram species is influenced by enhanced UV-B radiation. Oecologia, 133(1): 90-93.

Song, D., Shen, J., Li, L. (2010): Characterization of cellulose synthase complexes in Populus xylem differentiation. New Phytology, 187(3): 777-790.

Steffens, J. C., Harel, E. and Hunt, M. D. (1994): Polyphenol oxidase. In: Genetic engineering of plant secondary metabolism. Springer, Boston, pp. 275-312.

Sudachkova, N. E., Milyutina, I. L., Romanova L. I. and Semenova, G. P. (2004): The annual dynamics of reserve compounds and hydrolytic enzyme activity in the tissues of Pinus sylvestris L. and Larix sibirica Lebed. Eurasian Journal of Forest Research, 7(1): $1-10$.

TAN, K. H. (2005): Soil sampling, preparation, and analysis. CRC press, $672 \mathrm{p}$.

Thipy APONG, P., Hunt, M. D. and SteFFens, J. C. (2004): Antisense downregulation of polyphenol oxidase results in enhanced disease susceptibility. Planta, 220(1): 105-117.

Tombesi, L., Calè, M. T. and TiBorne, B. (1969): Effects of nitrogen, phosphorus and potassium fertilizers on the assimilation capacity of Beta vulgaris chloroplasts (I). Plant and Soil, 31(1): 65-76.

UusvaAra, O. (1974): Wood quality in plantation grown Scots pine. Communicationes Instituti Forestalis Fenniae, 80(2): 1-105.

Velling, P. (1976): Mänty-ja kuusiprovenienssien puuaineen tiheyden vaihtelusta. Folia Forestalia, 257: 1-32.

Wellen, K. E., Thompson, C. B. (2010): Cellular metabolic stress: considering how cells respond to nutrient excess. Molecular Cell, 40(2): 323-332.

WeLLWOOD, R.W. (1952): The effect of several variables on the specific gravity of second-growth Douglas fir. The Forestry Chronicle, 28(3): 34-42.

Wilson, I. D., Neill, S. J. and Hancock, J. T. (2008): Nitric oxide synthesis and signaling in plants. Plant, Cell and Environment, 31(5): 622-631.

Wind, C., AREND, M. and Fromm, J. (2004): Potassium dependent cambial growth in poplar. Plant Biology, 6(1): 30-37.

Xu, C., Natarajan, S. and Sullivan, J. H. (2008): Impact of solar ultraviolet-B radiation on the antioxidant defense system in soybean lines differing in flavonoid contents. Environmental and Experimental Botany, 63(1-3): 39-48.

Zbieć, I., Gurgul, E. and KArCZMARCZYK, S. (1986): Peroxidase and catalase activities in leaves of plants irrigated and fertilized with nitrogen. Zeszyty naukowe Akademii Rolniczej $w$ Szczecinie, 125: 175-180. (In Polish).

Zbieć, I., KarcZMarczyK, S., Kowalski, W., Friedrich, S. and Gurgul, E. (1989): Influence of water supply and mineral fertilizers on maize growth, structure of dyestuffs and activity of some enzymes in leaves. Zeszyty Problemowe Postępów Nauk Rolniczych, 343: 101-109. (In Polish).

Zu, Y. G., Pang, H. H., Yu, J. H., Li, D. W., Wei, X. X., GaO, Y. X. and Tong, L. (2010): Responses in the morphology, physiology and biochemistry of Taxus chinensis var. mairei grown under supplementary UV-B radiation. Journal of Photochemistry and Photobiology B: Biology, 98(2): 152-158. 
K. NIKEROVA et al.

\section{Web sources / Other sources}

[1] IUSS Working Group WRB (2015): World Reference Base for Soil Resources 2014, update 2015. International soil classification system for naming soils and creating legends for soil maps. World Soil Resources. Reports, 106. FAO, Rome.

[2] TAPPI (T222 om-11) (2011) Acid-insoluble lignin in wood and pulp, TAPPI Press, Atlanta, GA. 